\title{
The Complex Interplay between Chronic Inflammation, the Microbiome, and Cancer: Understanding Disease Progression and What We Can Do to Prevent It
}

\author{
Heather Armstrong ${ }^{1,2, *(\mathbb{D})}$, Michael Bording-Jorgensen ${ }^{1,3}$, Stephanie Dijk ${ }^{1,3}$ and \\ Eytan Wine 1,2,3 (D) \\ 1 CEGIIR, University of Alberta, Edmonton, AB T6G 2X8, Canada; bordingj@ualberta.ca (M.B.-J.); \\ sispragu@ualberta.ca (S.D.); wine@ualberta.ca (E.W.) \\ 2 Department of Pediatrics, University of Alberta, Edmonton, AB T6G 1C9, Canada \\ 3 Department of Physiology, University of Alberta, Edmonton, AB T6G 1C9, Canada \\ * Correspondence: harmstro@ualberta.ca; Tel.: +1-780-233-0380
}

Received: 1 March 2018; Accepted: 15 March 2018; Published: 20 March 2018

\begin{abstract}
Cancer is a multifaceted condition, in which a senescent cell begins dividing in an irregular manner due to various factors such as DNA damage, growth factors and inflammation. Inflammation is not typically discussed as carcinogenic; however, a significant percentage of cancers arise from chronic microbial infections and damage brought on by chronic inflammation. A hallmark cancer-inducing microbe is Helicobacter pylori and its causation of peptic ulcers and potentially gastric cancer. This review discusses the recent developments in understanding microbes in health and disease and their potential role in the progression of cancer. To date, microbes can be linked to almost every cancer, including colon, pancreatic, gastric, and even prostate. We discuss the known mechanisms by which these microbes can induce cancer growth and development and how inflammatory cells may contribute to cancer progression. We also discuss new treatments that target the chronic inflammatory conditions and their associated cancers, and the impact microbes have on treatment success. Finally, we examine common dietary misconceptions in relation to microbes and cancer and how to avoid getting caught up in the misinterpretation and over inflation of the results.
\end{abstract}

Keywords: cancer; microbiota; inflammation; diet

\section{Introduction}

The link between inflammation and cancer was first proposed by the German physician, Rudolf Virchow, in 1863 upon his discovery of white blood cells (leukocytes) within cancerous tissues [1]. While Virchow hypothesized that cancer could originate at sites of chronic inflammation [1], the last 150 years have seen a dramatic progression in our understanding of this topic (Figure 1: timeline of key dates in the understanding of inflammation and cancer). It was first proposed that a combination of specific irritants and tissue injuries, resulting in inflammation, increases the proliferative capacity of cells in the involved area, leading to sites of carcinogenesis [1]. The hallmark abnormal growth pattern of cells (neoplasia) associated with carcinogenesis is now known to involve far more than increased cell proliferation; Growth factors [2,3], DNA-damage-promoting agents [4,5], activated stroma [6], and a micro-environment rich in inflammatory cells [7] all contribute [1,8]. Advances in technology have enhanced our appreciation of the role of microbiota as environmental factors, beyond just causing infections. Interestingly, chronic inflammation involving microbes precedes development of a tumor site in up to $10-20 \%$ of cancers $[9,10]$. Furthermore, this inflammation can play a role in established tumors and in response to cancer therapeutics $[9,10]$. Research continues to improve 
our understanding of the molecular mechanisms, which mediate the complex relationship between inflammation, the microbiome, and cancer. In this review, we will focus on our current understanding of these relationships and what we can do to prevent disease progression. As novel approaches to treat and prevent cancer are critically needed, better defining the roles of microbes and inflammation can offer such unique opportunities in the future.

\section{Inflammation and Disease}

Inflammation represents a host response resulting from a number of factors including, but not limited to, pro-inflammatory mediators, environmental toxins, and chronic infection [11-13]. Importantly, in a cancer setting, inflammation plays a role in physiological processes such as controlling infection and wound healing, which are instrumental in disease development and progression, and have been highlighted well in other reviews [13]. Briefly, in response to tissue damage, host cells release various chemical signals, which initiate activation and directed migration of leukocytes (neutrophils, monocytes, and eosinophils) to the site of damage to repair afflicted tissues. The first leukocytes to be recruited in response to chemotactic signaling are neutrophils, which are responsible for stimulating the repair process and initiating inflammation $[13,14]$. This influx is followed by monocytes which, upon entry into the tissue, differentiate into macrophages. Local endothelial, epithelial, and mesenchymal cells are largely influenced by the growth factors and cytokines produced by activated macrophages. Chemokines, a family of chemotactic cytokines, direct the recruitment of specific leukocyte effector cells, thereby dictating the progression of the inflammatory response [1,15-17]. This is particularly important in chronic disease as abnormal, unremitting, inflammatory response can result from dysregulation of any of the cytokine/chemokine signaling factors. In contrast, site-specific inflammation in a normal setting is often thought to be self-limiting, due to the ensuing production of anti-inflammatory cytokines following the influx of pro-inflammatory cytokines. When dysregulated this process results in persistence of initiating factors or failed resolution of the inflammatory response. The subsequent chronic inflammation leads to subversion of cell death and repair programs and ultimately, contributes to cancer pathogenesis.

Studies have shown that use of agents, including non-steroidal anti-inflammatory drugs, is associated with protection against tumor growth and development, suggesting that chronic inflammation predisposes patients to various forms of cancer $[1,13,14,18,19]$. Further evidence has been provided by studies that show that most neoplastic tissues express an inflammatory component within their tissue microenvironment. This includes cancer types not obviously associated with inflammation and involves characteristic factors such as tissue remodeling, angiogenesis, tissue infiltration of leukocytes, predominance of tumor-associated macrophages (TAMs), and an increased presence of cytokines (tumor necrosis factor [TNF], interleukin [IL]-1, IL-6) and chemokines (CCL2 and CXCL8).

\section{Microbes as Drivers of Chronic Inflammation: The Link to Cancer}

Microorganisms colonize mucosal surfaces at birth and are involved in homeostatic processes including immune development and education and host defense through critical host-microbe, interkingdom signaling $[20,21]$. This is especially well recognized in the gut, which includes a similar number of microbial cells to the total number of human cells in the body, as evidenced by a profoundly underdeveloped immune system in germ-free animals [22]. Microbes are critical to many chronic inflammatory conditions, including, for example, inflammatory bowel diseases (IBD), arthritis, and primary sclerosing cholangitis, all of which are linked to cancer [23-26]. Indeed, animal models have supported a direct role for microbes in cancer pathogenesis in these conditions [27-29]. Following are examples of specific cancers clearly linked to exposure to microbes (Figure 1). 


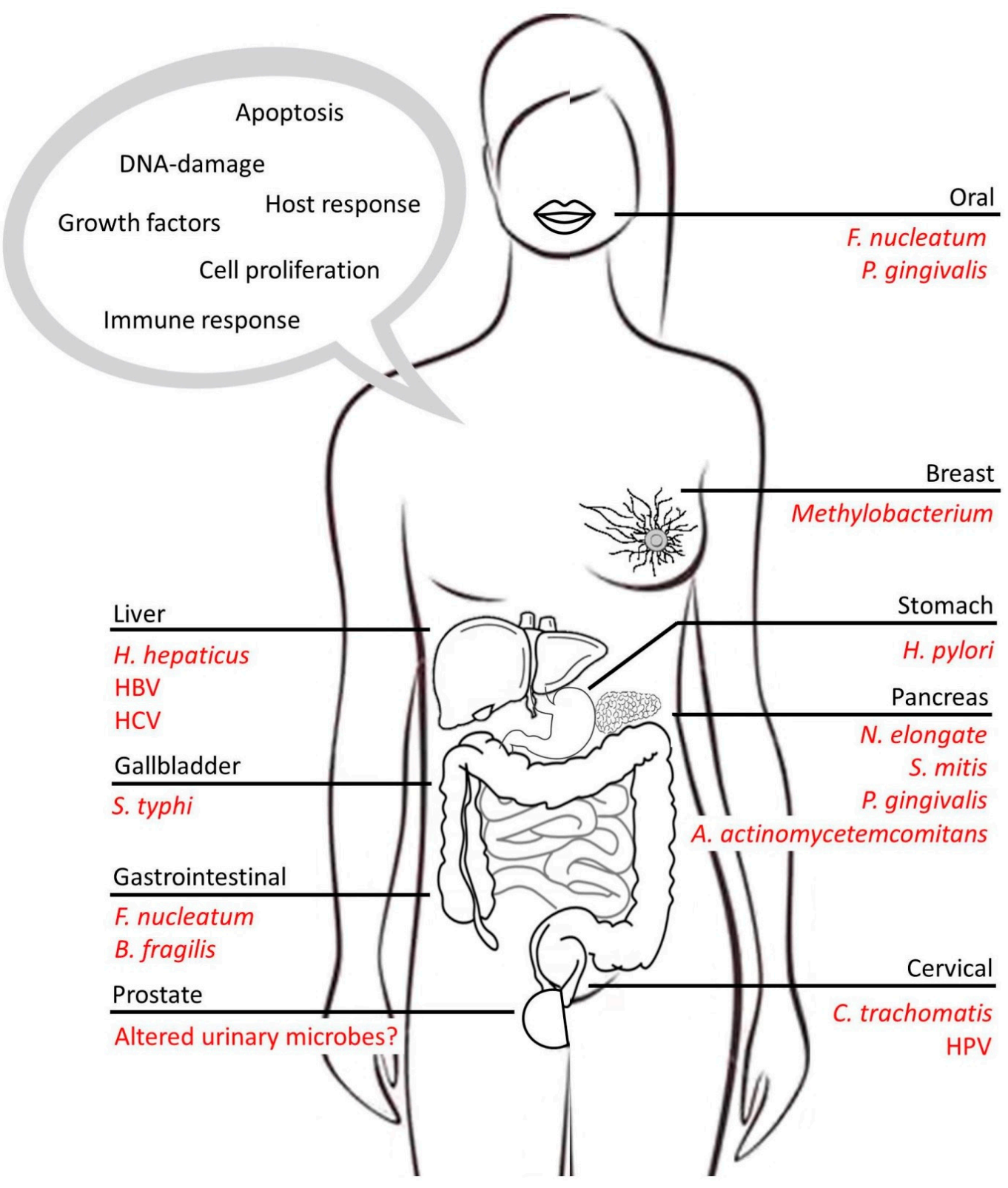

Figure 1. Highlighting the role of microbes in cancer and the key pathways mediated by microbes within host cells.

\subsection{Gastric Cancers}

One of the most common examples of inflammation-associated cancer involves the bacterium Helicobacter pylori, which can be found in the stomach of up to two thirds of the world's population [30]. $H$. pylori can promote host inflammatory responses through the production of virulence factors, including cytotoxin-associated gene $(\mathrm{Cag}) \mathrm{A}$, which interacts with and activates host inflammatory protein pathways such as MEK/ERK, NF- $\mathrm{KB}$, and $\beta$-catenin [31-34]. H. pylori was the first pathogen to be considered a carcinogen by the World Health Organization and has been identified as the culprit responsible for $70 \%$ of gastric adenocarcinomas, along with chronic gastritis, and lymphomas of the mucosa-associated lymphoid tissue (MALT) [35,36]. Interestingly, animal model studies have shown that mice infected with $\mathrm{H}$. pylori alone develop more extensive tumor profiles when compared to their germ-free and antibiotic-treated control populations [37,38]. Approximately $3 \%$ of patients infected with $H$. pylori will develop gastric cancer, suggesting that $H$. pylori may not be sufficient to cause 
cancer and is likely not acting alone in the development of inflammation-associated cancer. Infection by Epstein-Barr Virus (EBV) has also been associated with development of gastric cancers through aberrant gene methylation including RUNX1, RBM5, and PSME1 [39-41]. The outcome of infection also depends on environmental factors (e.g., smoking), host genetic predisposition (polymorphisms in genes encoding IL-1B, IL-10, TNF), and the crosstalk between strain-specific bacterial virulence factors (cagPAI, T4SS, CagA) [36,42-45]. Although gastric cancer incidence has been declining over the last few decades (likely due to an improved understanding of their cause and an increasing number of available therapeutics) they remain the second leading cause of cancer-related deaths worldwide [46].

\subsection{Liver Cancers}

Primary liver cancers, including the most common form known as hepatocellular carcinoma (HCC), remain the third leading cause of cancer-related deaths worldwide [47] and have been associated with hepatic injury and inflammation in up to $90 \%$ of cases [48]. Persistent chronic inflammation of the liver has been associated with liver fibrosis, cirrhosis, and subsequent HCC. Further studies have identified infection with Hepatitis B (HBV) or C (HCV) viruses, which result in liver inflammation, leading to increased risk of HCC development by almost 20-fold [47]. Both $\mathrm{HBV}$ and $\mathrm{HCV}$ are thought to result in liver damage and inflammation through the active response of CD8+ T- and natural killer (NK) cells [49,50]. Furthermore, in response to HBV and HCV viral infection, macrophage and neutrophils produce reactive oxygen species (ROS) and nitrogen compounds as a part of their inflammatory response, leading to DNA-damage associated with HCC and other cancers [49-51]. More recent studies have also implicated gut microbes such as Helicobacter hepaticus in the development of liver cancers, measured by tumor growth and induction of nuclear factor- $\mathrm{kB}$ (NF-kB) in response to intestinal colonization by Hepaticus [52].

\subsection{Pancreatic Cancers}

The increased risk of pancreatic cancer is also believed to be due to chronic inflammation and hyper-proliferation of pancreatic stellate cells [53]. Chronic pancreatitis can be brought on by a series of factors including environment factors (e.g., smoking), genetic predisposition, metabolic abnormalities, and infection [54]. Evidence accumulating from more recent studies in both human and animal models has suggested that specific microbes are also linked to inflammation associated with pancreatic cancer [55,56]. The presence of the periodontal pathogens Neisseria elongate, Streptococcus mitis, Porphyromonas gingivalis, and Aggregatibacter actinomycetemcomitans were closely associated with an increased risk of pancreatic cancer. Pancreatic cancer is characterized by very poor prognoses with a 5 -year survival rate below 7\%. Identification of specific microbes involved may provide important biomarkers to detect risk groups and aid in the development of targeted treatments towards these periodontal microbes, potentially preventing cancer development in the first place.

\subsection{Colorectal Cancer}

One of the most prevalent groups of chronic inflammatory diseases, IBD, is an important risk factor for the development of colorectal cancer (CRC), which is the third most common malignancy worldwide $[10,57]$. IBD-associated intestinal inflammation is characterized by site-specific influx of neutrophils, macrophages, and other immune cells [58-60]. Cytokines, free radicals, and proteolytic enzymes produced by these cells result in the hallmark inflammation and ulcerations found in IBD patients. Chronic inflammation associated with IBD can initiate tumourigenesis as the infiltrating immune cells within the intestinal tract create a microenvironment composed of elevated amounts of ROS and reactive nitrogen species (RNS) [61,62]. A build-up of ROS and RNS results in DNA damage and exogenous mutagens in surrounding tissues, promoting the initiation of cancer. The profile of cytokines and growth factors produced in IBD are similarly expressed in CRC and are vital for the growth of CRC tumors [10,57]. These include TNF, IL-1, IL-6, IL-17, IL-22, and IL-23 [63-74]. IBD is further characterized by dysbiosis or an altered microbiome that is thought to play a role in both the 
development of inflammation in IBD and progression to CRC. One bacterium, Fusobacterium nucleatum, has been shown, through metagenomics analysis, to be enriched in colorectal carcinoma tissues [75]. The direct role of F. nucleatum in the development of colorectal carcinoma is still not completely understood but it is clear that they play a significant role in its progression.

\subsection{Breast and Prostate Cancer}

Breast and prostate cancer are the leading causes of cancer death for women and men, respectively, and recent evidence suggests a role for inflammation and tissue microbes in disease pathogenesis [76-78]. The greatest microbial alteration found in breast tissue is a reduced abundance of Methylobacterium in breast cancer patients and has been correlated with tumors of greater invasive potential. Further perturbation of microbes whose products metabolize estrogen, and associated hormones cause circulating estrogen levels to increase, ultimately increasing the risk of breast cancer development.

In men with prostate cancer, the microenvironment of the prostate frequently contains inflammatory cells; therefore, studies have examined the role of inflammation and prostatic infection in prostate cancer development. It is thought that as development of prostate tumors progresses and oxygen supply is depleted, growth of anaerobic bacteria may become more prevalent [79]. Although identification of microbial involvement has proven complicated in prostate cancer, it has been established that inflammatory changes in the prostate microenvironment along with infection of the prostate are associated with epithelial barrier disruption, promoting prostate cancer development and progression [78]. Evidence suggests it is the altered microbiome of the urinary tract that leads to the potential for infection of the prostate $[78,80,81]$.

\section{Microbes and Inflammation}

Interestingly, as demonstrated in the examples above, one common trait shared among many chronic inflammatory diseases contributing to cancer is an altered microbiota, or the involvement of specific microbes (bacteria, viruses, fungi) in both inflammation and disease development [82]. A fine balance must be maintained between the beneficial commensal microorganisms and the pathogens attempting to establish themselves within the host. Gut commensals play a role in modulating host immunity, promoting host defense, synthesizing essential vitamins, and processing indigestible components of the hosts diet; while pathogens are involved in disease development and altering the host microenvironment to aid in establishing infection [83-85]. This alteration of the host microenvironment can eventually lead to dysbiosis in chronic conditions, thereby decreasing the benefits of the commensal microbiome.

Dysbiosis of the microbiome of the intestinal tract was observed in many disorders, and thus it is no surprise that there is a link with gastrointestinal carcinogenesis. Under normal physiological conditions, the gastrointestinal epithelial cells are protected by a mucous layer, which contains components that prevent direct interaction with many microbes as well as antimicrobial peptides. This mucous layer acts as a natural barrier, together with the immune system, to maintain microbes from the external environment at a healthy distance from the underlying host tissue [86]. This mucous lining is not a novel characteristic of the gut alone; it is also found in the lung, urethra, anus, and nose, among other organs [86]. However, many inflammatory conditions lead to a disruption of the mucosal layer allowing microbes to come into direct contact with the underlying tissue and epithelium [87].

The role of specific microbes in the development of cancer continues to be established [86,88]. If we recall that the presence of specific periodontal pathogens is associated with increased risk of pancreatic cancer, it is not surprising that a connection has also been established between the oral microbiome, such as Porphyromonas gingivalis and Fusobacterium nucleatum, and oral squamous cell carcinoma [88,89]. As mentioned previously, a number of microbes have been well established for their role in various cancers including H. pylori in MALT lymphomas, H. pylori and EBV in gastric cancer $[41,86,90]$, Bacteroides fragilis and Fusobacterium nucleatum in colon cancer [75,91], Human T lymphotropic 
virus (HTLV-1) in adult T-cell leukemia (ATL) [92,93], Chlamydia trachomatis and HPV in cervical cancer [94,95], EBV in Hodgkin's lymphoma (HL) [96,97], Salmonella typhi in gallbladder cancer [98], Fusobacterium and HPV in Head and neck squamous cell carcinomas (HNSCCs) [99,100], and KSHV in Kaposi's sarcoma (KS) [101]. One such study by Yakoob et al. recently demonstrated that patients with B-cell non-Hodgkin lymphoma were colonized with $H$. pylori that displayed increased expression of the outer membrane protein $H o p Q$. HopQ is a virulence factor that enables $H$. pylori adherence to gastric epithelial cells, establishing a mechanism for increased infection in these patients [102]. However, how are these microbes involved in the development of their associated cancers?

\section{Mechanism of Action of Microbes Associated with the Development of Cancer}

Cancer pathogenesis involves a number of factors including a micro-environment rich in inflammatory cells [7], growth factors [2,3], DNA-damage-promoting agents [4,5], activated stroma [6], induced cell proliferation, and inhibition of apoptosis, among other factors $[1,8]$. Specific microbes display unique characteristics in their ability to regulate changes in their host niche which can result in an increased risk of associated cancers. Some of these targets and examples of microbes involved are presented below.

\subsection{Regulation of Immune Cells}

It comes as no surprise that under conditions of chronic inflammation the microenvironment would be rich in inflammatory cells; however, the role of immune cells in cancer growth is quite complex. A number of reviews highlight the complex interplay of immune cells and the tumor environment, which is beyond the focus of this paper [103-105]. Recent research has demonstrated another layer of depth, examining the role that microbes play in regulating specific processes of immunity in the context of cancer development. For example, the presence of T-cells in cancerous tissues has been associated with an increased patient survival [106,107]. One bacterium, F. nucleatum, possesses a virulence factor that can suppress T-cell activity similar to $H$. pylori in gastric cancer. Mima et al. have recently shown that there is an inverse relationship between the numbers of F. nucleatum present in a tissue and the amount of CD3+ T-cells [55,108]. This suggests that this bacterium is suppressing T-cell activity in patients, thereby allowing for cancer development, and possibly impacting response to treatment. In fact, many therapies under development aim to mobilize T-cell populations to seek and destroy tumor cells [109], a common goal of immunotherapies (discussed below in more detail). Another study by Kuhn et al. demonstrated Bacteroidales to be important for intestinal membrane integrity by stimulating intraepithelial lymphocyte secretion of IL-6; however, while low levels of IL-6 are tolerable, increased levels of IL-6 promotes tumourigenesis by signaling proliferation, angiogenesis, and invasiveness while inhibiting apoptosis [110,111]. Cytokines such as IL-1 $\beta$, TNF- $\alpha$, and IL-6 are also produced by cells infected with viruses including Epstein-Barr Virus (EBV), HBV, HCV, and Kaposi's sarcoma herpesvirus (KSHV), which induces an inflammatory environment and promotes tumourigenesis [112-114]. This highlights the importance of elucidating the healthy balance of microbes within the body, and specifically the gut. Recognizing the role of microbes in regulating these immune cells may provide an alternative to immunotherapies through the use of microbe-altering diets and targeted therapeutics.

Alternatively, in some cancers such as intestinal cancers, the role of microbes may be less direct. While the immune system of a healthy patient displays a level of tolerance for commensal microbes, immune-impairment, such as found in patients with chronic inflammatory conditions, can lead to inappropriate immune responses towards microbes resulting in intestinal tumor growth $[115,116]$.

\subsection{Growth Factors}

Induced expression of growth hormones is mediated in part by microbes that prompt senescent cells to secrete growth factors, which has been shown to enable tumor growth [117]. One study demonstrated that $E$. coli species that produce the genotoxin colibactin, induce tumor growth by 
increasing production of hepatocyte growth factor in human and mouse colon cancer models [117]. Further studies in colorectal cancer patients and mouse models indicated that an increase in specific E. coli strains expressing the $p k s$ pathogenicity island produce the genotoxin colibactin $[118,119]$. Colibactin promotes tumourigenesis through the production of growth factors as a result of alterations in the SUMOylation of p53 [118,119]. Transforming growth factor beta (TGF $\beta$ ) plays a variable role in the regulation of cell growth, proliferation, differentiation, and apoptosis, depending on the cell type and state. In benign cells it has been shown to inhibit cell cycle however, in cancer cells, TGF $\beta$ promotes tumor cells growth and metastasis through the promotion of ERK pathways [120]. A number of infectious agents, including influenza A virus, Group A Streptococcus, and Staphylococcus aureus utilize TGF $\beta$ [121-123]. Interestingly, blocking growth factor production using TGF $\beta$ inhibitors or Smad3 signaling inhibitors results in reduced secretion of extracellular matrix components involved in bacterial binding and therefore has been demonstrated to reduce Group A Streptococcus (fibronectin-binding) abundance [122,123]. Furthermore, by reducing the secretion of extracellular matrix proteins, these inhibitors prevent tumor cell dissemination, proliferation, and metastasis [124-128].

Binding of ligands to one of the most well studied growth factor receptors, epidermal growth factor receptor (EGFr), results in activation of cell signaling pathways, causes mass protein phosphorylation, and leads to cytoskeletal reorganization promoting tumourigenesis [129]. EGFr ligands play a role in regulating gastrin production by H. pylori, as inhibiting EGFr has been shown to reduce gastrin expression, thereby reducing risk of tumourigenesis [130]. Interaction of microbes, such as H. pylori, with host cells modulates host cell signaling pathways involved in the promotion of cancer, such as mitogen-activated protein kinase (MAPK) pathway, integrin-mediated signaling, and heparin-binding EGF-like growth factor (HB-EGF) pathways [130-132]. Interestingly, use of probiotics (microbes with potential beneficial effects) such as E. coli Nissle 1917, leads to epithelial wound healing through interactions of the microbes with EGFr, which would suggest potential therapeutic use of this system for gastrointestinal mucosa, and other epithelial tissue repair [133]. This highlights the important interplay between host cells and both the commensal and pathogenic microbes found within the host and the host microenvironment [134].

\subsection{Promoting the Hallmarks of Cancer}

Tumourigenesis has been shown to be directly modulated by specific microbes through the production of toxins including genotoxins. Genotoxins are known to result in the production of tumor-promoting metabolites, and further induce DNA damage. The host cell responses to DNA damage are affected by microbe-produced toxins including, $B$. fragilis toxin, cytotoxic necrotizing factor 1 , cytolethal distending toxin (CDT), and colibactin, which have been implicated in tumorigenesis [118,135]. CDT is produced by a number of species associated with gastric cancer, colorectal cancer, and gallbladder cancer, such as E. coli, S. typhi, and H. pylori [136]. Genomic instability may also result from metabolites (hydrogen sulfide and superoxide radicals) produced by microbes [137,138]. For example, colorectal tumors develop in mice in response to large amounts of superoxide radicals produced by the bacterium Enterococcus faecalis, which have been shown to result in chromosome instability and double-strand DNA breaks $[139,140]$. A number of microbial species including E. coli, Campylobacter jejuni, Aggregatibacter actinomycetemcomitans, Haemophilus ducreyi, Shigella dysenteriae, Helicobacter hepaticus, and S. enterica produce the genotoxin compound of the CDTs family, which display potent DNase activity causing DNA lesions and apoptosis [141].

Protein A of $S$. aureus is known to stimulate phosphorylation of EGFr, which in turn leads to phosphorylation and activation of ADAM17 [129,142-144]. Stimulation of EGFr results in cell proliferation, increased survival, cellular differentiation, adhesion, and migration [145]. Regulation of EGFr and its associated pathways has been linked to gastric, colon, liver, lung, and pancreatic cancers [146-151]. For example, in an inflammatory microenvironment, activation of signal transducer and activator of transcription (STAT) 3 by IL-6 promotes proliferation of pre-malignant cells and 
inhibits apoptosis $[148,149,152]$. Proliferation is promoted by STAT3 through upregulation of cyclin D1, cyclin D2, and cyclin B cell cycle regulators, along with the MYC transcription factor $[148,149,153]$. Furthermore, STAT3 upregulates expression of the anti-apoptotic genes BCL2 and BCL2-like 1 (BCL2L1) resulting in reduced apoptosis and promotion of tumourigenesis.

\section{Microbes and Inflammation in Cancer: Means of Treatment and Prevention}

\subsection{Response to Chemotherapy}

Several currently available cancer therapeutics are listed with summaries provided by the National Cancer Institute (available at: https: / / www.cancer.gov/about-cancer/treatment/drugs) while those currently undergoing clinical trial for possible FDA approval have been listed by the National Institute of Health (available at: https: / clinicaltrials.gov / ct2 $/$ results? cond=Cancer\&term $=\&$ cntry $=\&$ state $=$ \&city $=\&$ dist=). Platinum-based antineoplastic compounds, often referred to as platins, are used to treat up to $50 \%$ of all cancer patients [154-156]. Studies performed in animal models demonstrate that the antitumor activity of platins is reduced in the absence of commensal microbes and although the compounds remain detectable within tumors, DNA damage is dramatically attenuated [157]. These agents function to induce apoptosis and cytotoxicity in tumor cells by inhibiting DNA replication through the formation of double-stranded breaks and intrastrand platinum-DNA adducts [158-161]. This process is driven by microbes that promote production of ROS via NADPH oxidase 2 (NOX2) by tumor-infiltrating myeloid cells [157]. For example, addition of Lactobacillus acidophilus to germ-free mice restores the antitumor activity of cisplatin [162]. Interestingly, platins also result in severe intestinal toxicity, nephrotoxicity, and peripheral neuropathy, which can be attenuated by the addition of the probiotic L. acidophilus $[162,163]$. It is not surprising, based on these data, that targeting the microbiota through the use of prebiotics (complex carbohydrates that promote growth of beneficial microbes), probiotics, and symbiotics (combined probiotics and prebiotics) has the potential to limit toxicity while improving therapeutic efficacy [164].

Microbes play an important role in regulating the pharmacokinetics, toxicity, and mechanism of action of chemotherapeutics [134,165]. For example, gut microbes metabolize injected compounds, such as the intravenous topoisomerase I inhibitor, CPT-11 (tissue carboxylesterase transforms Irinotecan), used for colorectal cancer treatment [166]. CPT-11 is converted to its active form, SN-38, and further detoxified to inactive SN-38-G in the liver by UDP-glucuronosyltransferases [166]. In the gut, SN-38-G is converted back to $\mathrm{SN}-38$ by bacterial $\beta$-Glucuronidase, most often associated with Firmicutes, particularly clostridia, resulting in intestinal toxicity, diarrhea, and intestinal inflammation [166-169]. These symptoms can be prevented in patients with high abundance of $\beta$-glucuronidase-positive bacteria through the use of targeted antibiotics or bacterial $\beta$-glucuronidase-specific inhibitors [169]. Further, bacterial enzyme production is altered in response to xenobiotics, including chemotherapeutics, and these enzymes regulate bioavailability of many oral compounds $[170,171]$. Another example relates to gemcitabine, a chemotherapeutic agent commonly used for treating pancreatic ductal adenocarcinoma. Gammaproteobacteria were found to have the capacity to metabolize gemcitabine into an inactive metabolite through the bacterial enzyme cytidine deaminase $\left(\mathrm{CDD}_{\mathrm{L}}\right)$; this effect was reversed by use of antibiotics [172]. Interestingly, viruses including EBV have developed techniques to augment viral expansion by encoding the Epstein-Barr virus (EBV) homologue of the BCL-2 proto-oncogene, BHRF1, which prevents apoptosis of the infected cells and confers a strong level of chemoresistance [173-175]. As small molecule inhibitors of Bcl-2 do not target BHRF1, studies have examined targeted inhibitors of BHRF1, such as BINDI, and have demonstrated induced apoptosis in EBV-infected cancer cell lines and reduced tumor growth in xenograft models of EBV-positive human lymphoma $[175,176]$. These studies suggest viral-targeted therapies may improve the prognosis of viral-associated cancers.

Microbial composition is also altered in response to some antitumor agents, such as the alkylating agent cyclophosphamide (CTX) [177,178]. CTX allows gut microbes, including Lactobacillus johnsonii, Lactobacillus murinus, and Enterococcus hirae to translocate across the epithelial barrier by increasing 
mucosal permeability in the gut $[177,178]$. Treatment with CTX also results in reduction of Treponema (Spirochaetes), Clostridium (Firmicutes), Roseburia (Firmicutes), Coprococcus (Firmicutes), and Lachnospiraceae (Firmicutes), and increases abundance of L. johnsonii, L. murinus, E. hirae, and L. reuteri [177]. This shift in microbes results in activation of memory T helper (Th) 1 and pathogenic pTh17 cells and CTX antitumor effects can be reduced in mice treated with targeted antibiotics [177,179].

\subsection{Immunotherapy}

One of the most successful interventions for patients suffering from metastatic disease following treatment failure is immunotherapy, which recent studies have demonstrated to be modulated by the composition of the gut microbiota [157,180-182]. Immune checkpoint inhibitors, such as the programmed cell death protein 1(PD-1) inhibitors, are highly effective in some patients with advanced melanoma, non-small cell lung cancer, and renal cell carcinoma by suppressing the interaction of $\mathrm{T}$ inhibitory receptors with their associated ligands on tumor cells, thus promoting cytotoxic and memory T lymphocyte-mediated immune responses [183,184]. Antibiotic treatment in patients prior to anti-PD-1 therapy reduced progression-free and overall survival of patients compared to those who had not taken antibiotics. Interestingly, increased abundance of the gut bacterium Akkermansia muciniphila was associated with improved clinical response to anti-PD-1 treatment, likely due to T-cell mediated response promoted by release of IL-12 in response to A. muciniphila [183]. Increased abundance of the Clostridiales order and the Faecalibacterium genus, associated with increased CD8+ T cells, demonstrated greater response to anti-PD-1 therapy and experienced longer progression-free survival [184]. Members of the Bacteroidales order were associated with poorer outcomes and demonstrated diminished cytokine response and increased levels of myeloid-derived suppressor cells and circulating regulatory T cells associated with reduced antitumor immunity [184]. Other studies suggest that Bifidobacterium may reduce tumor growth through manipulation of dendritic cell function, improving the anti-tumor activity of cytotoxic T cells [181]. In many ways, bacteria that would typically worsen immune-mediated conditions have a favorable effect in the setting of cancer immunotherapy and vice versa. The reason for this is likely the need for a proinflammatory response against the tumor to promote effectiveness of immunotherapy [185]. The efficacy of an anti-cytotoxic T-lymphocyte-associated protein 4 (CTLA4) immunotherapeutics can also be improved by enhancing the antitumor activity of cytotoxic T-cell populations with increased abundance of Bacteroides thetaiotamicron and nontoxigenic Bacteroides fragilis [182]. The polysaccharide A (PSA) of $B$. fragilis has been shown to regulate the balance between effector and regulatory $\mathrm{T}$ cells, resulting in enhance antitumor immunity and promoting an anti-inflammatory state [182,186,187]. Interestingly, the $B$. fragilis toxin (BFT) has recently been shown to trigger pro-carcinogenic inflammatory pathways in colonic epithelial cells through IL-17R, NF- $\mathrm{B}$, and STAT3 indicating the potential pathogenic role this bacterium may play [188].

\subsection{Diet as a Bridge between Microbes and Cancer}

While there are innumerous cancer therapeutic interventions available to date, one of the key intervention strategies remaining to be fully elucidated is the role of diet both in disease development and prevention, as well as the role of diet in regulating the human microbiome (Figure 2). It has been well established that a diet rich in fruit and vegetables reduce the risk of lung, throat, larynx, and mouth cancers; unfortunately, diet can be very difficult to measure and control in an experimental setting in a human cohort due to differences in portion size, food availability, and adherence to the particular diet [189-192]. Fruits and vegetables contain a large number of nutrients including folate, vitamin C, vitamin E, carotenoids, flavonoids, selenium, and natural fibers-all associated with reduced risk of gastrointestinal cancers [193-195]. An important series of studies has demonstrated that the key nutrients found in fruits and vegetables do not reduce cancer risk when taken as supplements and may in fact display harmful effects in these instances [196,197]. The adaptation of microbiota to dietary intake has been seen in a Japanese diet rich in seaweed, which has been associated with promotion of the 
Bacteroides plebeius in the human gut to acquire enzymes for seaweed digestion from the marine bacteria Zobellia galactanivorans [198]. Recent studies in human breast cancer cell lines have demonstrated that the polysaccharides (SWP1 and SWP2) isolated from the brown seaweed Sargassum wightii (SWP) significantly reduced cell proliferation and induced apoptosis in a dose-dependent manner [199].

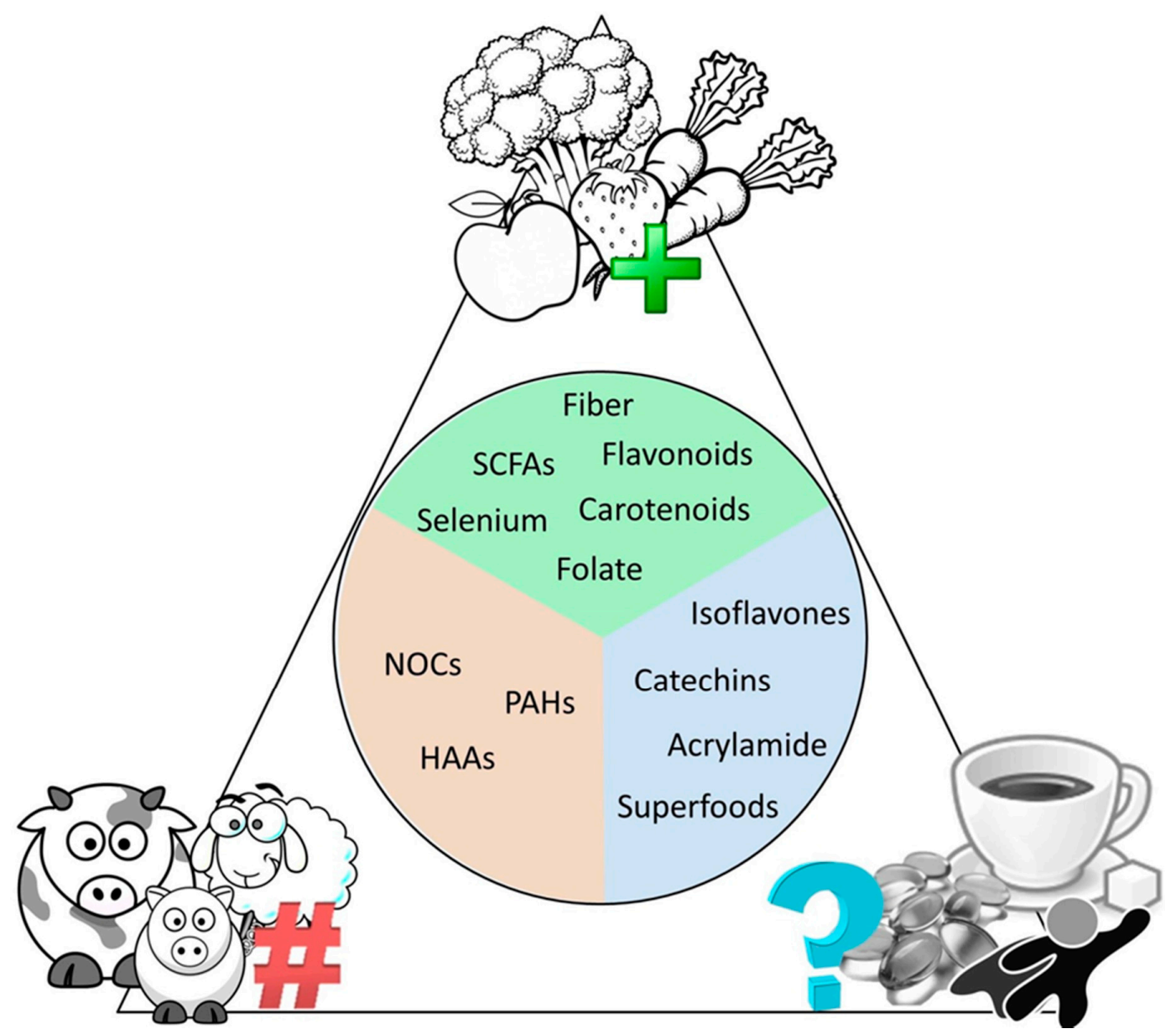

Figure 2. The current consensus on dietary interventions in cancer. What the research studies performed on dietary factors say about their positive, negative, or unknown effects on cancer risk.

As the gut microbiota clearly plays an important role in inflammation and cancer prevention, introduction of a diverse number of beneficial live bacteria and yeast through probiotics are a promising option for use in establishing and promoting a healthy microbiota. Probiotic bacteria have been shown to display anti-cancer properties in a number of studies by suppressing the growth of microbes involved in the production of mutagens and carcinogens, altering metabolism of carcinogens, protecting DNA from oxidative damage, and regulating the immune system [200]. Natural fermented milk products such as Kefir have been shown to inhibit breast cancer cell proliferation in vitro when compared to normal breast epithelia [201]. Specific studies have elucidated the molecules produced by probiotic microbes which are responsible for their anti-tumor effects. One such study by Konishi et al. identified ferrichrome as the molecule produced by Lactobacillus casei which is responsible for the probiotic microbes tumor-suppressive effects [202]. The anti-tumor effects of ferrichrome in colon cancer cells were shown to be even greater than cisplatin and 5-fluorouracil and demonstrated less effect on non-cancerous cells in vitro when compared to either of these clinical agents [202]. While these, and other, results are promising, there are over 400 probiotic strains within the human intestine and there currently remains a lack of clear guidelines on appropriate timing for use of probiotics along with a lack of clear evidence to determine which probiotics are most effective. The effectiveness of a probiotic 
supplement is dependent on species diversity, dose, and disease status of the patient [203]. To date, clinical studies have shown that probiotics are effective in patients with a number of ailments including acute infectious diarrhea, antibiotic-associated diarrhea, Clostridium difficile-associated diarrhea, hepatic encephalopathy, ulcerative colitis, irritable bowel syndrome, functional gastrointestinal disorders, and necrotizing enterocolitis [203]. Probiotics have not been shown to be effective in Crohn disease or acute pancreatitis [203]. While in vitro and in vivo studies remain promising, a great deal of clinical research remains to be done to improve our understanding of the effectiveness of probiotics. (Lescheid et al.).

A number of studies have also associated a diet high in red meat, that when consumed more than twice a week may increase the risk of gastrointestinal, pancreatic, and prostate cancers [204-210]. In these studies, red meat includes fresh, minced, and frozen lamb, beef, pork, and processed meats including, sausages, bacon, ham, and salami [204]. Research recommends that a maximum of $70 \mathrm{~g}$ or $0.15 \mathrm{lb}$ of red meat should be consumed daily to reduce this risk. While a causative link remains to be identified, some research suggested that the haem pigment, found only in red meat, could stimulate production of cancer causing N-nitroso compounds (NOCs) by gut bacteria; the nitrites and nitrates used as preservatives in processed meats can also be converted to NOCs within the body. Alternatively, heterocyclic aromatic amines (HAAs) and polycyclic aromatic hydrocarbons (PAHs) formed when cooking meat at high temperatures, may result in increased risk of cancer [207,211,212].

One key nutrient group under continued investigation is the bacterial metabolites known as short chain fatty acids (SCFAs). In the human gut, dietary fibers are fermented by microbes, resulting in the formation of predominantly acetate, propionate, and butyrate SCFAs [213,214]. SCFAs, which generally have protective roles, enter into the colonic epithelium at varying rates through diffusion and carrier-mediated mechanisms; however, in patients with cancer or chronic inflammatory diseases, such as colitis and arthritis, altered expression of these transport proteins results in reduced uptake of SCFAs [215]. Interestingly, supplementation with acetate has been shown to reduce inflammation in vivo peripherally in arthritis, and acetate stimulation in vitro reduced pro-inflammatory surface receptors on human neutrophils [216]. Furthermore, increasing the fermentable fiber inulin in the diet has been shown to significantly elevate concentrations of SCFA and lower the ratio of omega 6 to 3 essential fatty acids (EFAs) in mice, which has previously been associated with reduced incidence of cancer, inflammation, and other chronic diseases in humans [217]. Mouse model studies demonstrate that inulin-type fructan dietary supplementation increases propionate levels in the portal vein and slows infiltration of transplanted cancer cells [218]. In vitro exposure of these cancer cells to propionate slowed proliferation compared to controls [218]. In vitro treatment of human colon cancer cells with the SCFA butyrate increased expression of the cyclin dependent kinase inhibitor, p21 [219], which has previously been shown by immunohistochemistry to be lost in 79\% of colon cancer tumors [220]. As SCFAs are obtained by dietary fibers, these findings provide insight into the results of the Aune et al. metaanalysis that described increased fiber intake is associated with a reduced risk of colorectal cancer [221].

Other micronutrients of note in cancer prevention include isothiocyanates and lignans. The isothiocyanate glucoraphanin in cruciferous vegetables is antineoplastic and anti-inflammatory after activation to the bioactive sulforaphane by a heat sensitive enzyme [222,223]. If the converting enzyme, also present in cruciferous vegetables, is heat destroyed in cooking, conversion to sulforaphane relies on metabolism by the gut microbiome [223]. There is great variability between individuals, with the ability to convert sulforaphane into the active form found to range from $1 \%$ to $40 \%$ [223]. Sulforaphane has been demonstrated to inhibit malignant growth in various cancer types and has recently been shown to inhibit proliferation of gefitinab resistant lung cancer cells suggesting combination of sulforaphane and gefitinib may provide a more effective therapy for lung cancer [224]. It is very important to note that as with all dietary factors, a large proportion of sulforaphane (up to 70\%) is excreted in the patients urine within the first $24 \mathrm{~h}$ helping explain its ability to prevent bladder cancer invasion [225,226]. Furthermore, while doses ranging from 1-12 $\mu \mathrm{M}$ have been shown to display antitumourigenic effects in cell lines, oral doses of $150 \mu \mathrm{M}$ or greater are required to elicit 
response [224,225]. Beverage formulation of sulforaphane was prepared by re-hydrating previously lyophilized 3-day-old broccoli sprout powders produced from specially selected BroccoSprouts seeds (DM1999B) boiled and aqueous extracted [225]. Lignans, found in plant parts such as seed coats and bran are associated with decreased breast and colon cancer, and are converted into the anti-tumor enterolignans, through metabolism in separate steps by several unique gut bacteria [227]. Enterolignans are associated with a decreased risk of colorectal cancer among women in the EPIC study, but a slight increased risk of prostate cancer in men [228]. Recent studies in laboratory models of colitis in mice have shown that brown rice, a great source of insoluble fiber, is able to alleviate inflammatory symptoms therefore, offering potential to reduce risk of inflammation-associated colorectal cancers [229].

A Dietary Inflammatory Index $\left(\mathrm{DII}^{\circledR}\right)$ was developed to categorize patient diets according to inflammatory potential, in which a higher score equates to a greater risk of inflammation [230]. A number of studies support the importance of establishing an anti-inflammatory diet to prevent the development of cancers, especially those of the gastrointestinal tract [230]. Many foods listed in the DII ${ }^{\circledR}$ have been shown to display anti-inflammatory properties, including certain flavonoids (found in many fruits and vegetables) and the spices and herbs: saffron, turmeric, oregano, and eugenol (from cloves) [230-232]. Pro-inflammatory foods in the DII ${ }^{\circledR}$ include dietary cholesterol, trans fat, and saturated fat [230-232]. Studies performed in rats on a high sucrose diet demonstrate that diet supplementation with the flavonoids quercetin and resveratrol reduces the ratio of Firmicutes/Bacteroidetes and ultimately reduces weight gain and insulin resistance compared to rats on a high sucrose diet without supplementation [233]. Microbiota changes are also found in response to supplementation with the active compound of turmeric, curcumin, including reduction in Prevotellacea and increased Bacteroidaceae and Rikenellaceae [234]. Other studies evaluating curcumin supplementation in the IL-10 ${ }^{-/-}$mouse model of colitis associated cancer demonstrated increases in Lactobacillus, which has previously been shown to help prevent colorectal cancer $[235,236]$.

\subsection{Common Dietary Misconceptions}

While several fantastic studies have been completed linking diet to microbes, inflammation, and their associated cancers, it is important to distinguish these from several popular theories, often referenced in discussion with patients and researchers alike. Many of these dietary factors have little to no scientific evidence to support their role in disease promotion or prevention and are an over-extrapolation of very specific scientific findings. For example, as mentioned earlier, vitamin supplements do not necessarily provide the same health benefits as naturally-obtained vitamin sources and several clinical trials examining the effect of vitamin supplements in cancer have found that high doses of certain supplements can in fact increase cancer risk [196,197,237]. The Cochrane Collaboration, which continues to examine results from a series of clinical trials, has found that results from over 80 clinical trials prove that vitamin supplements pose either a neutral effect or increased health risk with no health benefit compared to a diet without supplements [238-241]. It is important to remember that the microbes in our gut participate in the production and bioavailability of many dietary nutrients, including SCFAs [213,214,242]; therefore, maintaining a healthy, balanced flora is essential for maintaining balanced nutrient levels. These studies demonstrate that supplements do not substitute a healthy balanced diet high in fruits and vegetables, although for some patients, supplements are essential to combat a lack of nutrient. Examples of this include calcium supplementation in patients taking steroids [243]; folic acid supplementation for women planning to have a baby [244]; vitamin D supplementation in those at risk of low vitamin D levels including children under 5 , adults over 65 , pregnant or breastfeeding women, or those with sun sensitivities, among others [245].

Further examples include the chemical acrylamide and artificial sweeteners as cancer causing agents, and calcium as an anti-tumourigenic agent. While evidence from animal models suggests a link between these examples and cancer risk [246-250], evidence from human studies is weak [251-254] and requires more diligence in study design to understand any potential link. Some evidence has demonstrated that microbes, namely bacteria, produce the enzyme, amidase, which decomposes 
acrylamide [255]. Furthermore, acrylamide appears to be utilized as a carbon source for lactic acid bacteria $[255,256]$. Artificial sweeteners are commonly used in a variety of foods and drinks and the most extensively studied sweeteners including saccharin and aspartame have been shown to alter microbial composition [248,257-260]. Calcium is important for tooth and bone health and has further been shown to play a role in cell structure, motility, and transport in a variety of microorganisms [261]. While there is little direct evidence of the role these agents play in direct regulation of microbes in inflammation and cancer, research continues to uncover more evidence to elucidate the mechanisms of their interactions.

An interesting new term in recent years coined "superfood" has been used to describe foods with apparent health benefits and is often applied to foods including blueberries, broccoli, raspberries, and green tea, among other foods. While the sales pitch of this term has suggested these foods can prevent diseases, including cancer, it is simply a marketing tool with very little scientific basis to back these claims; marketing distorts scientific findings, over generalizing and selectively ignoring negating data. While we highlighted earlier the importance of a well-balanced diet to reduce risk of cancer, it is incredibly unlikely that a single food item or superfood will have any major effect alone. These foods are often labeled superfoods as they contain natural chemicals, which have been shown to display positive health effects in a laboratory setting such as antioxidants, vitamins, and minerals, some of which were listed earlier [262,263]. It is important here to recall however that the amount of many chemicals found in foods are trace amounts compared to their purified and isolated forms used in research. These isolated chemicals often behave very differently in a test tube used in a laboratory setting in animals or cell culture methods and often these experiments require very high doses of purified chemical to demonstrate any effect. Extensive studies have been performed on green tea as it contains high levels of polyphenols, including catechins, and anti-inflammatory flavonoids, which have been demonstrated to be beneficial in inhibiting cancer growth in a laboratory setting [264-266]. Furthermore, while both black and green tea have been demonstrated to inhibit $H$. pylori with no inhibition on the beneficial gut bacterium L. acidophilus [267], large scale studies in humans demonstrate no conclusive beneficial association or reduced risk of pancreatic, lung, breast, prostate, stomach, bowel, thyroid, liver, endometrial, laryngeal, bladder, ovarian, kidney, or esophageal cancers $[268,269]$. One issue with the transition of clinical efficacy from animal models to human trials may be due to limited bioavailability of polyphenols, however more remains to be examined to better identify appropriate dosing and bioavailability for clinical studies [270] Interestingly, studies promoting the benefit of green tea in cancer have shown that microbes including Pseudomonas sp., E. coli, Bifidobacterium sp., Lactobacillus sp., Bacteroides sp. and, Eubacterium sp., utilize polyphenols such as catechins as a carbon source [271-273]. Catechins are catalyzed to protocatechuic acid which has been shown to inhibit metastasis in vitro and is naturally found in fruits and vegetables [272,273]. Flavonoids have also been shown to display anti-tumourigenic effects in cells lines and are hydroxylated by microbes including Aspergillus, an abundant fungi of the gut $[271,274,275]$. The isoflavones found in soy or soya products such as tofu, are plant-based estrogens extracted from soybeans and display similar structure to, but more mild effects compared to human estrogen [276-278]. Laboratory studies have demonstrated the potential use of isoflavones to reduce risk of certain hormone-associated cancers, such as prostate cancer, although studies in humans have produced unclear results [279]. More research is needed to identify the link between isoflavones and cancer at this time; however, initial studies suggest, again, a role for intestinal bacteria in the metabolism of soy isoflavonoids [280], demonstrating the importance of identifying the healthy balance of microbes within the human gut in order to better understand how dietary factors can play a role in promoting or preventing cancer.

\section{The Take Home Message}

Cancer remains one of the most prevalent group of diseases in the developed world and is a leading cause of deaths worldwide. While a great deal has been discovered about carcinogenesis and the role that DNA damage, growth factors, and inflammation play in both cancer development and 
progression, we have only made it through the tip of the iceberg in our understanding of the role of microbes in maintaining health and altering the host environment for the promotion of inflammation and cancer. Here we have highlighted the prominent studies that have progressed our understanding of the role microbes play, far beyond the gastrointestinal system. These studies demonstrate a role for microbes in almost every cancer including colon, pancreatic, gastric, and even prostate. It remains imperative that we identify the microbes involved in maintaining health, so we may promote their growth and prevent the growth of those identified to be involved in disease development and treatment failure. As technologies (especially high-throughput sequencing) continue to evolve, we expect that data associating microbes with cancer will continue to amount and will stimulate further research and clinical trials.

How can our understanding of microbes, inflammation, and cancer lead to improved outcomes for patients? Promoting colonization of healthy microbes with probiotics, prebiotics, and symbiotics offers promising results for preventing the development of inflammation, along with inhibiting cancer progression and amplifying the effects of specific anti-cancer therapeutics; however, these products will rarely lead to a long-term effect and a more holistic approach may be required. Some beneficial microbes can be introduced by consuming fermented foods including yogurt products or kefirs, fermented kimchi or sauerkraut, or clinically available probiotic products, to name a few. These microbes require the correct nutrients to survive and thrive so simply consuming them may not aid in the quest for ultimate health. As mentioned earlier, a diet rich in fruits and vegetables, and natural fibers is essential for the sustained health and growth of the microbiota. The loss of these microbes, as seen in dysbiosis, can have a large impact on host health. One of these impacts discussed in this review is the progression of cancer.

Together with the emergence of high-tech treatments to manipulate signaling and immune response, such as immunotherapy, as novel approaches to combat cancer, more attention should be paid to "low-tech", life style changes that can directly impact the long-term risk of cancer through defined metabolic pathways involving microbes. One of the biggest challenges with this area of research is the need for long term studies (over decades) as well as the poor ability to measure diet over time. Metabolomics, which allows precise measurement of small molecules (many of which are derived from microbes, diet, and the interaction between them), could add to the science of this field. Through combining basic, translational, and clinical research (including epidemiologic studies), novel microbe-altering approaches could revolutionize cancer care and prevention by reducing chronic inflammation and progression to cancer.

Acknowledgments: We graciously acknowledge our funding sources for covering the costs to publish in an open access journal. E.W. was supported by grants from Crohn's and Colitis Foundation, Crohn's and Colitis Canada, Alberta Innovates-Health Solutions (AIHS), and Women \& Children's Health Research Institute (WCHRI). The funders had no role in the preparation or completion of this manuscript.

Author Contributions: H.A. wrote the manuscript with assistance from M.B.-J., S.D., and E.W. All authors were equally involved in editing the manuscript and have approved of the final version.

Conflicts of Interest: The authors have no conflicts of interest directly related to this research.

\section{Abbreviations}

$\begin{array}{ll}\text { BFT } & \text { B. fragilis toxin } \\ \text { Cag } & \text { cytotoxin-associated gene } \\ \text { CDDL } & \text { cytidine deaminase } \\ \text { CDT } & \text { cytolethal distending toxin } \\ \text { CRC } & \text { colorectal cancer } \\ \text { CPT-11 } & \text { tissue carboxylesterase transforms Irinotecan } \\ \text { CTLA4 } & \text { anti-cytotoxic T-lymphocyte-associated protein } 4 \\ \text { CTX } & \text { cyclophosphamide } \\ \text { DII } & \text { epidermal growth factor receptor }\end{array}$




$\begin{array}{ll}\text { EFAs } & \text { essential fatty acids } \\ \text { HAAs } & \text { heterocyclic aromatic amines } \\ \text { HB-EGF } & \text { heparin-binding EGF-like growth factor } \\ \text { HBV } & \text { Hepatitis B } \\ \text { HCC } & \text { hepatocellular carcinoma } \\ \text { HCV } & \text { Hepatitis C } \\ \text { IBD } & \text { inflammatory bowel diseases } \\ \text { IL } & \text { interleukin } \\ \text { MALT } & \text { mucosa-associated lymphoid tissue } \\ \text { MAPK } & \text { mitogen-activated protein kinase } \\ \text { NF-kB } & \text { nuclear factor- } k \text { B } \\ \text { NK } & \text { natural killer } \\ \text { NOCs } & \text { N-nitroso compounds } \\ \text { NOX2 } & \text { NADPH oxidase 2 } \\ \text { PAHs } & \text { polycyclic aromatic hydrocarbons } \\ \text { PD-1 } & \text { programmed cell death protein 1 } \\ \text { PSA } & \text { polysaccharide A } \\ \text { ROS } & \text { reactive oxygen species } \\ \text { RNS } & \text { reactive nitrogen species } \\ \text { SCFAs } & \text { short chain fatty acids } \\ \text { STAT3 } & \text { signal transducer and activator of transcription 3 } \\ \text { TGF } \beta & \text { Transforming growth factor beta } \\ \text { Th } & \text { T helper } \\ \text { TAMs } & \text { tumor-associated macrophages } \\ \text { TNF } & \text { tumor necrosis factor }\end{array}$

\section{References}

1. Balkwill, F.; Mantovani, A. Inflammation and cancer: Back to virchow? Lancet 2001, 357, 539-545. [CrossRef]

2. Lashinger, L.M.; Ford, N.A.; Hursting, S.D. Interacting inflammatory and growth factor signals underlie the obesity-cancer link. J. Nutr. 2014, 144, 109-113. [CrossRef] [PubMed]

3. Landskron, G.; De la Fuente, M.; Thuwajit, P.; Thuwajit, C.; Hermoso, M.A. Chronic inflammation and cytokines in the tumor microenvironment. J. Immunol. Res. 2014. [CrossRef] [PubMed]

4. Kidane, D.; Chae, W.J.; Czochor, J.; Eckert, K.A.; Glazer, P.M.; Bothwell, A.L.; Sweasy, J.B. Interplay between DNA repair and inflammation, and the link to cancer. Crit. Rev. Biochem. Mol. Biol. 2014, 49, 116-139. [CrossRef] [PubMed]

5. Kawanishi, S.; Ohnishi, S.; Ma, N.; Hiraku, Y.; Murata, M. Crosstalk between DNA damage and inflammation in the multiple steps of carcinogenesis. Int. J. Mol. Sci. 2017, 18, 1808. [CrossRef] [PubMed]

6. Li, H.; Fan, X.; Houghton, J. Tumor microenvironment: The role of the tumor stroma in cancer. J. Cell. Biochem. 2007, 101, 805-815. [CrossRef] [PubMed]

7. Korniluk, A.; Koper, O.; Kemona, H.; Dymicka-Piekarska, V. From inflammation to cancer. Ir. J. Med. Sci. 2017, 186, 57-62. [CrossRef] [PubMed]

8. Dvorak, H.F. Tumors: Wounds that do not heal. Similarities between tumor stroma generation and wound healing. N. Engl. J. Med. 1986, 315, 1650-1659. [PubMed]

9. Grivennikov, S.I. Inflammation and colorectal cancer: Colitis-associated neoplasia. Semin. Immunopathol. 2013, 35, 229-244. [CrossRef] [PubMed]

10. Grivennikov, S.I.; Greten, F.R.; Karin, M. Immunity, inflammation, and cancer. Cell 2010, 140, 883-899. [CrossRef] [PubMed]

11. Shacter, E.; Weitzman, S.A. Chronic inflammation and cancer. Oncology 2002, 16, 217-226. [PubMed]

12. Rubin, D.C.; Shaker, A.; Levin, M.S. Chronic intestinal inflammation: Inflammatory bowel disease and colitis-associated colon cancer. Front. Immunol. 2012, 3, 107. [CrossRef] [PubMed]

13. Coussens, L.M.; Werb, Z. Inflammation and cancer. Nature 2002, 420, 860-867. [CrossRef] [PubMed]

14. Colotta, F.; Allavena, P.; Sica, A.; Garlanda, C.; Mantovani, A. Cancer-related inflammation, the seventh hallmark of cancer: Links to genetic instability. Carcinogenesis 2009, 30, 1073-1081. [CrossRef] [PubMed] 
15. Rossi, D.; Zlotnik, A. The biology of chemokines and their receptors. Annu. Rev. Immunol. 2000, 18, $217-242$. [CrossRef] [PubMed]

16. Homey, B.; Muller, A.; Zlotnik, A. Chemokines: Agents for the immunotherapy of cancer? Nat. Rev. Immunol. 2002, 2, 175-184. [CrossRef] [PubMed]

17. Moustakas, A. Smad signalling network. J. Cell Sci. 2002, 115, 3355-3356. [PubMed]

18. Balkwill, F.; Charles, K.A.; Mantovani, A. Smoldering and polarized inflammation in the initiation and promotion of malignant disease. Cancer Cell 2005, 7, 211-217. [CrossRef] [PubMed]

19. Mantovani, A.; Allavena, P.; Sica, A.; Balkwill, F. Cancer-related inflammation. Nature 2008, 454, 436-444. [CrossRef] [PubMed]

20. Houghteling, P.D.; Walker, W.A. Why is initial bacterial colonization of the intestine important to infants' and children's health? J. Pediatr. Gastroenterol. Nutr. 2015, 60, 294-307. [CrossRef] [PubMed]

21. Walker, A. Intestinal colonization and programming of the intestinal immune response. J. Clin. Gastroenterol. 2014, 48 (Suppl. 1), S8-S11. [CrossRef] [PubMed]

22. Fiebiger, U.; Bereswill, S.; Heimesaat, M.M. Dissecting the interplay between intestinal microbiota and host immunity in health and disease: Lessons learned from germfree and gnotobiotic animal models. Eur. J. Microbiol. Immunol. 2016, 6, 253-271. [CrossRef] [PubMed]

23. Ong, H.S.; Yim, H.C.H. Microbial factors in inflammatory diseases and cancers. Adv. Exp. Med. Biol. 2017, 1024, 153-174. [PubMed]

24. Karlsen, T.H.; Folseraas, T.; Thorburn, D.; Vesterhus, M. Primary sclerosing cholangitis-A comprehensive review. J. Hepatol. 2017, 67, 1298-1323. [CrossRef] [PubMed]

25. Maeda, Y.; Takeda, K. Role of gut microbiota in rheumatoid arthritis. J. Clin. Med. 2017, 6, 60. [CrossRef] [PubMed]

26. Mellemkjaer, L.; Linet, M.S.; Gridley, G.; Frisch, M.; Moller, H.; Olsen, J.H. Rheumatoid arthritis and cancer risk. Eur. J. Cancer 1996, 32A, 1753-1757. [CrossRef]

27. Sussman, D.A.; Santaolalla, R.; Strobel, S.; Dheer, R.; Abreu, M.T. Cancer in inflammatory bowel disease: Lessons from animal models. Curr. Opin. Gastroenterol. 2012, 28, 327-333. [CrossRef] [PubMed]

28. Yoshimoto, S.; Loo, T.M.; Atarashi, K.; Kanda, H.; Sato, S.; Oyadomari, S.; Iwakura, Y.; Oshima, K.; Morita, H.; Hattori, M.; et al. Obesity-induced gut microbial metabolite promotes liver cancer through senescence secretome. Nature 2013, 499, 97-101. [CrossRef] [PubMed]

29. Li, S.; Yu, Y.; Yue, Y.; Zhang, Z.; Su, K. Microbial infection and rheumatoid arthritis. J. Clin. Cell. Immunol. 2013, 4, 174. [PubMed]

30. Fox, J.G.; Wang, T.C. Inflammation, atrophy, and gastric cancer. J. Clin. Investig. 2007, 117, 60-69. [CrossRef] [PubMed]

31. Wang, F.; Meng, W.; Wang, B.; Qiao, L. Helicobacter pylori-induced gastric inflammation and gastric cancer. Cancer Lett. 2014, 345, 196-202. [CrossRef] [PubMed]

32. Mueller, D.; Tegtmeyer, N.; Brandt, S.; Yamaoka, Y.; De Poire, E.; Sgouras, D.; Wessler, S.; Torres, J.; Smolka, A.; Backert, S. C-src and c-abl kinases control hierarchic phosphorylation and function of the caga effector protein in western and east asian helicobacter pylori strains. J. Clin. Investig. 2012, 122, 1553-1566. [CrossRef] [PubMed]

33. Brandt, S.; Kwok, T.; Hartig, R.; Konig, W.; Backert, S. Nf-kappab activation and potentiation of proinflammatory responses by the helicobacter pylori caga protein. Proc. Natl. Acad. Sci. USA 2005, 102, 9300-9305. [CrossRef] [PubMed]

34. Franco, A.T.; Israel, D.A.; Washington, M.K.; Krishna, U.; Fox, J.G.; Rogers, A.B.; Neish, A.S.; Collier-Hyams, L.; Perez-Perez, G.I.; Hatakeyama, M.; et al. Activation of beta-catenin by carcinogenic helicobacter pylori. Proc. Natl. Acad. Sci. USA 2005, 102, 10646-10651. [CrossRef] [PubMed]

35. Ekstrom, A.M.; Held, M.; Hansson, L.E.; Engstrand, L.; Nyren, O. Helicobacter pylori in gastric cancer established by caga immunoblot as a marker of past infection. Gastroenterology 2001, 121, 784-791. [CrossRef] [PubMed]

36. Peek, R.M., Jr.; Crabtree, J.E. Helicobacter infection and gastric neoplasia. J. Pathol. 2006, 208, $233-248$. [CrossRef] [PubMed]

37. Lofgren, J.L.; Whary, M.T.; Ge, Z.; Muthupalani, S.; Taylor, N.S.; Mobley, M.; Potter, A.; Varro, A.; Eibach, D.; Suerbaum, S.; et al. Lack of commensal flora in helicobacter pylori-infected ins-gas mice reduces gastritis and delays intraepithelial neoplasia. Gastroenterology 2011, 140, 210-220. [CrossRef] [PubMed] 
38. Lee, C.W.; Rickman, B.; Rogers, A.B.; Ge, Z.; Wang, T.C.; Fox, J.G. Helicobacter pylori eradication prevents progression of gastric cancer in hypergastrinemic ins-gas mice. Cancer Res. 2008, 68, 3540-3548. [CrossRef] [PubMed]

39. Cheng, X.J.; Lin, J.C.; Tu, S.P. Etiology and prevention of gastric cancer. Gastrointest. Tumors 2016, 3, 25-36. [CrossRef] [PubMed]

40. Qu, Y.; Dang, S.; Hou, P. Gene methylation in gastric cancer. Clin. Chim. Acta Int. J. Clin. Chem. 2013, 424, 53-65. [CrossRef] [PubMed]

41. Verma, R.; Sharma, P.C. Next generation sequencing-based emerging trends in molecular biology of gastric cancer. Am. J. Cancer Res. 2018, 8, 207-225. [PubMed]

42. Camargo, M.C.; Mera, R.; Correa, P.; Peek, R.M., Jr.; Fontham, E.T.; Goodman, K.J.; Piazuelo, M.B.; Sicinschi, L.; Zabaleta, J.; Schneider, B.G. Interleukin-1beta and interleukin-1 receptor antagonist gene polymorphisms and gastric cancer: A meta-analysis. Cancer Epidemiol. Biomark. 2006, 15, 1674-1687. [CrossRef] [PubMed]

43. El-Omar, E.M.; Carrington, M.; Chow, W.H.; McColl, K.E.; Bream, J.H.; Young, H.A.; Herrera, J.; Lissowska, J.; Yuan, C.C.; Rothman, N.; et al. Interleukin-1 polymorphisms associated with increased risk of gastric cancer. Nature 2000, 404, 398-402. [CrossRef] [PubMed]

44. Fischer, W.; Puls, J.; Buhrdorf, R.; Gebert, B.; Odenbreit, S.; Haas, R. Systematic mutagenesis of the helicobacter pylori cag pathogenicity island: Essential genes for caga translocation in host cells and induction of interleukin-8. Mol. Microbiol. 2001, 42, 1337-1348. [CrossRef] [PubMed]

45. Krisch, L.M.; Posselt, G.; Hammerl, P.; Wessler, S. Caga phosphorylation in helicobacter pylori-infected b cells is mediated by the nonreceptor tyrosine kinases of the src and abl families. Infect. Immun. 2016, 84, 2671-2680. [CrossRef] [PubMed]

46. Ferlay, J.; Shin, H.R.; Bray, F.; Forman, D.; Mathers, C.; Parkin, D.M. Estimates of worldwide burden of cancer in 2008: Globocan 2008. Int. J. Cancer 2010, 127, 2893-2917. [CrossRef] [PubMed]

47. El-Serag, H.B.; Rudolph, K.L. Hepatocellular carcinoma: Epidemiology and molecular carcinogenesis. Gastroenterology 2007, 132, 2557-2576. [CrossRef] [PubMed]

48. Bishayee, A. The role of inflammation and liver cancer. Adv. Exp. Med. Biol. 2014, 816, 401-435. [PubMed]

49. Buchmann, P.; Dembek, C.; Kuklick, L.; Jager, C.; Tedjokusumo, R.; von Freyend, M.J.; Drebber, U.; Janowicz, Z.; Melber, K.; Protzer, U. A novel therapeutic hepatitis b vaccine induces cellular and humoral immune responses and breaks tolerance in hepatitis b virus (hbv) transgenic mice. Vaccine 2013, 31, 1197-1203. [CrossRef] [PubMed]

50. Nakamoto, Y.; Guidotti, L.G.; Kuhlen, C.V.; Fowler, P.; Chisari, F.V. Immune pathogenesis of hepatocellular carcinoma. J. Exp. Med. 1998, 188, 341-350. [CrossRef] [PubMed]

51. Jackson, S.P.; Bartek, J. The DNA-damage response in human biology and disease. Nature 2009, 461, 1071-1078. [CrossRef] [PubMed]

52. Fox, J.G.; Feng, Y.; Theve, E.J.; Raczynski, A.R.; Fiala, J.L.; Doernte, A.L.; Williams, M.; McFaline, J.L.; Essigmann, J.M.; Schauer, D.B.; et al. Gut microbes define liver cancer risk in mice exposed to chemical and viral transgenic hepatocarcinogens. Gut 2010, 59, 88-97. [CrossRef] [PubMed]

53. Algul, H.; Treiber, M.; Lesina, M.; Schmid, R.M. Mechanisms of disease: Chronic inflammation and cancer in the pancreas-A potential role for pancreatic stellate cells? Nat. Clin. Pract. Gastroenterol. Hepatol. 2007, 4, 454-462. [CrossRef] [PubMed]

54. Kleeff, J.; Whitcomb, D.C.; Shimosegawa, T.; Esposito, I.; Lerch, M.M.; Gress, T.; Mayerle, J.; Drewes, A.M.; Rebours, V.; Akisik, F.; et al. Chronic pancreatitis. Nat. Rev. Dis. Prim. 2017, 3, 17060. [CrossRef] [PubMed]

55. Mima, K.; Nakagawa, S.; Sawayama, H.; Ishimoto, T.; Imai, K.; Iwatsuki, M.; Hashimoto, D.; Baba, Y.; Yamashita, Y.I.; Yoshida, N.; et al. The microbiome and hepatobiliary-pancreatic cancers. Cancer Lett. 2017, 402, 9-15. [CrossRef] [PubMed]

56. Fan, X.; Alekseyenko, A.V.; Wu, J.; Peters, B.A.; Jacobs, E.J.; Gapstur, S.M.; Purdue, M.P.; Abnet, C.C.; Stolzenberg-Solomon, R.; Miller, G.; et al. Human oral microbiome and prospective risk for pancreatic cancer: A population-based nested case-control study. Gut 2016. [CrossRef] [PubMed]

57. Tenesa, A.; Dunlop, M.G. New insights into the aetiology of colorectal cancer from genome-wide association studies. Nat. Rev. Genet. 2009, 10, 353-358. [CrossRef] [PubMed]

58. Szigethy, E.; McLafferty, L.; Goyal, A. Inflammatory bowel disease. Child Adolesc. Psychiatr. Clin. N. Am. 2010, 19, 301-318. [CrossRef] [PubMed] 
59. De Souza, H.S.; Fiocchi, C. Immunopathogenesis of ibd: Current state of the art. Nat. Rev. Gastroenterol. Hepatol. 2016, 13, 13-27. [CrossRef] [PubMed]

60. Stokkers, P.C.; Hommes, D.W. New cytokine therapeutics for inflammatory bowel disease. Cytokine 2004, 28, 167-173. [CrossRef] [PubMed]

61. Greten, F.R.; Eckmann, L.; Greten, T.F.; Park, J.M.; Li, Z.W.; Egan, L.J.; Kagnoff, M.F.; Karin, M. Ikkbeta links inflammation and tumorigenesis in a mouse model of colitis-associated cancer. Cell 2004, 118, 285-296. [CrossRef] [PubMed]

62. Hussain, S.P.; Hofseth, L.J.; Harris, C.C. Radical causes of cancer. Nat. Rev. Cancer 2003, 3, 276-285. [CrossRef] [PubMed]

63. Francescone, R.; Hou, V.; Grivennikov, S.I. Cytokines, ibd, and colitis-associated cancer. Inflamm. Bowel Dis. 2015, 21, 409-418. [CrossRef] [PubMed]

64. Neurath, M.F. Cytokines in inflammatory bowel disease. Nat. Rev. Immunol. 2014, 14, 329-342. [CrossRef] [PubMed]

65. Popivanova, B.K.; Kitamura, K.; Wu, Y.; Kondo, T.; Kagaya, T.; Kaneko, S.; Oshima, M.; Fujii, C.; Mukaida, N. Blocking tnf-alpha in mice reduces colorectal carcinogenesis associated with chronic colitis. J. Clin. Investig. 2008, 118, 560-570. [PubMed]

66. Atreya, R.; Mudter, J.; Finotto, S.; Mullberg, J.; Jostock, T.; Wirtz, S.; Schutz, M.; Bartsch, B.; Holtmann, M.; Becker, C.; et al. Blockade of interleukin 6 trans signaling suppresses t-cell resistance against apoptosis in chronic intestinal inflammation: Evidence in crohn disease and experimental colitis in vivo. Nat. Med. 2000, 6, 583-588. [CrossRef] [PubMed]

67. Kai, Y.; Takahashi, I.; Ishikawa, H.; Hiroi, T.; Mizushima, T.; Matsuda, C.; Kishi, D.; Hamada, H.; Tamagawa, H.; Ito, T.; et al. Colitis in mice lacking the common cytokine receptor gamma chain is mediated by il-6-producing CD4+ T cells. Gastroenterology 2005, 128, 922-934. [CrossRef] [PubMed]

68. Ng, S.C.; Benjamin, J.L.; McCarthy, N.E.; Hedin, C.R.; Koutsoumpas, A.; Plamondon, S.; Price, C.L.; Hart, A.L.; Kamm, M.A.; Forbes, A.; et al. Relationship between human intestinal dendritic cells, gut microbiota, and disease activity in crohn's disease. Inflamm. Bowel Dis. 2011, 17, 2027-2037. [CrossRef] [PubMed]

69. Izcue, A.; Hue, S.; Buonocore, S.; Arancibia-Carcamo, C.V.; Ahern, P.P.; Iwakura, Y.; Maloy, K.J.; Powrie, F. Interleukin-23 restrains regulatory $t$ cell activity to drive $t$ cell-dependent colitis. Immunity 2008, 28, 559-570. [CrossRef] [PubMed]

70. Cox, J.H.; Kljavin, N.M.; Ota, N.; Leonard, J.; Roose-Girma, M.; Diehl, L.; Ouyang, W.; Ghilardi, N. Opposing consequences of il-23 signaling mediated by innate and adaptive cells in chemically induced colitis in mice. Mucosal Immunol. 2012, 5, 99-109. [CrossRef] [PubMed]

71. Yen, D.; Cheung, J.; Scheerens, H.; Poulet, F.; McClanahan, T.; McKenzie, B.; Kleinschek, M.A.; Owyang, A.; Mattson, J.; Blumenschein, W.; et al. Il-23 is essential for $\mathrm{t}$ cell-mediated colitis and promotes inflammation via il-17 and il-6. J. Clin. Investig. 2006, 116, 1310-1316. [CrossRef] [PubMed]

72. Fujino, S.; Andoh, A.; Bamba, S.; Ogawa, A.; Hata, K.; Araki, Y.; Bamba, T.; Fujiyama, Y. Increased expression of interleukin 17 in inflammatory bowel disease. Gut 2003, 52, 65-70. [CrossRef] [PubMed]

73. Seiderer, J.; Elben, I.; Diegelmann, J.; Glas, J.; Stallhofer, J.; Tillack, C.; Pfennig, S.; Jurgens, M.; Schmechel, S.; Konrad, A.; et al. Role of the novel th17 cytokine il-17f in inflammatory bowel disease (ibd): Upregulated colonic il-17f expression in active crohn's disease and analysis of the il17f p.His161arg polymorphism in ibd. Inflamm. Bowel Dis. 2008, 14, 437-445. [CrossRef] [PubMed]

74. Sugimoto, K.; Ogawa, A.; Mizoguchi, E.; Shimomura, Y.; Andoh, A.; Bhan, A.K.; Blumberg, R.S.; Xavier, R.J.; Mizoguchi, A. Il-22 ameliorates intestinal inflammation in a mouse model of ulcerative colitis. J. Clin. Investig. 2008, 118, 534-544. [CrossRef] [PubMed]

75. Kostic, A.D.; Gevers, D.; Pedamallu, C.S.; Michaud, M.; Duke, F.; Earl, A.M.; Ojesina, A.I.; Jung, J.; Bass, A.J.; Tabernero, J.; et al. Genomic analysis identifies association of fusobacterium with colorectal carcinoma. Genome Res. 2012, 22, 292-298. [CrossRef] [PubMed]

76. Wang, H.; Altemus, J.; Niazi, F.; Green, H.; Calhoun, B.C.; Sturgis, C.; Grobmyer, S.R.; Eng, C. Breast tissue, oral and urinary microbiomes in breast cancer. Oncotarget 2017, 8, 88122-88138. [CrossRef] [PubMed]

77. Mani, S. Microbiota and breast cancer. Prog. Mol. Biol. Transl. Sci. 2017, 151, 217-229. [PubMed]

78. Sfanos, K.S.; Yegnasubramanian, S.; Nelson, W.G.; De Marzo, A.M. The inflammatory microenvironment and microbiome in prostate cancer development. Nat. Rev. Urol. 2018, 15, 11-24. [CrossRef] [PubMed] 
79. Bhudia, R.; Ahmad, A.; Akpenyi, O.; Whiley, A.; Wilks, M.; Oliver, T. Identification of low oxygen-tolerating bacteria in prostate secretions of cancer patients and discussion of possible aetiological significance. Sci. Rep. 2017, 7, 15164. [CrossRef] [PubMed]

80. Arora, H.C.; Eng, C.; Shoskes, D.A. Gut microbiome and chronic prostatitis/chronic pelvic pain syndrome. Ann. Transl. Med. 2017, 5, 30. [CrossRef] [PubMed]

81. Shrestha, E.; White, J.R.; Yu, S.H.; Kulac, I.; Ertunc, O.; De Marzo, A.M.; Yegnasubramanian, S.; Mangold, L.A.; Partin, A.W.; Sfanos, K.S. Profiling the urinary microbiome in men with positive versus negative biopsies for prostate cancer. J. Urol. 2018, 199, 161-171. [CrossRef] [PubMed]

82. Francescone, R.; Hou, V.; Grivennikov, S.I. Microbiome, inflammation, and cancer. Cancer J. 2014, 20, $181-189$. [CrossRef] [PubMed]

83. Martin, R.; Miquel, S.; Ulmer, J.; Kechaou, N.; Langella, P.; Bermudez-Humaran, L.G. Role of commensal and probiotic bacteria in human health: A focus on inflammatory bowel disease. Microb. Cell Fact. 2013, $12,71$. [CrossRef] [PubMed]

84. Silva, M.J.; Carneiro, M.B.; dos Anjos Pultz, B.; Pereira Silva, D.; Lopes, M.E.; dos Santos, L.M. The multifaceted role of commensal microbiota in homeostasis and gastrointestinal diseases. J. Immunol. Res. 2015, 2015, 321241. [CrossRef] [PubMed]

85. Engering, A.; Hogerwerf, L.; Slingenbergh, J. Pathogen-host-environment interplay and disease emergence. Emerg. Microb. Infect. 2013, 2, e5. [CrossRef] [PubMed]

86. Raskov, H.; Burcharth, J.; Pommergaard, H.C. Linking gut microbiota to colorectal cancer. J. Cancer 2017, 8 , 3378-3395. [CrossRef] [PubMed]

87. Alipour, M.; Zaidi, D.; Valcheva, R.; Jovel, J.; Martinez, I.; Sergi, C.; Walter, J.; Mason, A.L.; Wong, G.K.; Dieleman, L.A.; et al. Mucosal barrier depletion and loss of bacterial diversity are primary abnormalities in paediatric ulcerative colitis. J. Crohn's Colitis 2016, 10, 462-471. [CrossRef] [PubMed]

88. Perera, M.; Al-Hebshi, N.N.; Speicher, D.J.; Perera, I.; Johnson, N.W. Emerging role of bacteria in oral carcinogenesis: A review with special reference to perio-pathogenic bacteria. J. Oral Microbiol. 2016, 8, 32762. [CrossRef] [PubMed]

89. Lim, Y.; Totsika, M.; Morrison, M.; Punyadeera, C. Oral microbiome: A new biomarker reservoir for oral and oropharyngeal cancers. Theranostics 2017, 7, 4313-4321. [CrossRef] [PubMed]

90. Mager, D.L. Bacteria and cancer: Cause, coincidence or cure? A review. J. Transl. Med. 2006, 4, 14. [CrossRef] [PubMed]

91. Toprak, N.U.; Yagci, A.; Gulluoglu, B.M.; Akin, M.L.; Demirkalem, P.; Celenk, T.; Soyletir, G. A possible role of bacteroides fragilis enterotoxin in the aetiology of colorectal cancer. Clin. Microbiol. Infect. 2006, 12, 782-786. [CrossRef] [PubMed]

92. Hinuma, Y.; Nagata, K.; Hanaoka, M.; Nakai, M.; Matsumoto, T.; Kinoshita, K.I.; Shirakawa, S.; Miyoshi, I. Adult $\mathrm{t}$-cell leukemia: Antigen in an atl cell line and detection of antibodies to the antigen in human sera. Proc. Natl. Acad. Sci. USA 1981, 78, 6476-6480. [CrossRef] [PubMed]

93. Satou, Y.; Yasunaga, J.; Yoshida, M.; Matsuoka, M. Htlv-i basic leucine zipper factor gene mrna supports proliferation of adult T cell leukemia cells. Proc. Natl. Acad. Sci. USA 2006, 103, 720-725. [CrossRef] [PubMed]

94. Markowska, J.; Fischer, N.; Markowski, M.; Nalewaj, J. The role of chlamydia trachomatis infection in the development of cervical neoplasia and carcinoma. Medycyna Wieku Rozwojowego 2005, 9, 83-86. [PubMed]

95. Burd, E.M. Human papillomavirus and cervical cancer. Clin. Microbiol. Rev. 2003, 16, 1-17. [CrossRef] [PubMed]

96. Young, L.S.; Rickinson, A.B. Epstein-barr virus: 40 years on. Nat. Rev. Cancer 2004, 4, 757-768. [CrossRef] [PubMed]

97. Raab-Traub, N. Novel mechanisms of ebv-induced oncogenesis. Curr. Opin. Virol. 2012, 2, 453-458. [CrossRef] [PubMed]

98. Nagaraja, V.; Eslick, G.D. Systematic review with meta-analysis: The relationship between chronic salmonella typhi carrier status and gall-bladder cancer. Aliment. Pharmacol. Ther. 2014, 39, 745-750. [CrossRef] [PubMed]

99. Leemans, C.R.; Snijders, P.J.F.; Brakenhoff, R.H. The molecular landscape of head and neck cancer. Nat. Rev. Cancer 2018. [CrossRef] [PubMed] 
100. Shin, J.M.; Luo, T.; Kamarajan, P.; Fenno, J.C.; Rickard, A.H.; Kapila, Y.L. Microbial communities associated with primary and metastatic head and neck squamous cell carcinoma-A high fusobacterial and low streptococcal signature. Sci. Rep. 2017, 7, 9934. [CrossRef] [PubMed]

101. Hansen, A.; Boshoff, C.; Lagos, D. Kaposi sarcoma as a model of oncogenesis and cancer treatment. Expert Rev. Anticancer Ther. 2007, 7, 211-220. [CrossRef] [PubMed]

102. Yakoob, J.; Abbas, Z.; Ahmad, Z.; Tariq, K.; Awan, S.; Mustafa, K.; Khan, R. Gastric lymphoma: Association with helicobacter pylori outer membrane protein $\mathrm{q}$ (hopq) and cytotoxic-pathogenicity activity island (cpai) genes. Epidemiol. Infect. 2017, 145, 3468-3476. [CrossRef] [PubMed]

103. Goubran, H.A.; Kotb, R.R.; Stakiw, J.; Emara, M.E.; Burnouf, T. Regulation of tumor growth and metastasis: The role of tumor microenvironment. Cancer Growth Metastasis 2014, 7, 9-18. [CrossRef] [PubMed]

104. Gajewski, T.F.; Schreiber, H.; Fu, Y.X. Innate and adaptive immune cells in the tumor microenvironment. Nat. Immunol. 2013, 14, 1014-1022. [CrossRef] [PubMed]

105. Bremnes, R.M.; Al-Shibli, K.; Donnem, T.; Sirera, R.; Al-Saad, S.; Andersen, S.; Stenvold, H.; Camps, C.; Busund, L.T. The role of tumor-infiltrating immune cells and chronic inflammation at the tumor site on cancer development, progression, and prognosis: Emphasis on non-small cell lung cancer. J. Thorac. Oncol. 2011, 6, 824-833. [CrossRef] [PubMed]

106. Liu, K.; Yang, K.; Wu, B.; Chen, H.; Chen, X.; Chen, X.; Jiang, L.; Ye, F.; He, D.; Lu, Z.; et al. Tumor-infiltrating immune cells are associated with prognosis of gastric cancer. Medicine 2015, 94, e1631. [CrossRef] [PubMed]

107. Kmiecik, J.; Poli, A.; Brons, N.H.; Waha, A.; Eide, G.E.; Enger, P.O.; Zimmer, J.; Chekenya, M. Elevated $\mathrm{CD} 3+$ and CD8+ tumor-infiltrating immune cells correlate with prolonged survival in glioblastoma patients despite integrated immunosuppressive mechanisms in the tumor microenvironment and at the systemic level. J. Neuroimmunol. 2013, 264, 71-83. [CrossRef] [PubMed]

108. Mima, K.; Cao, Y.; Chan, A.T.; Qian, Z.R.; Nowak, J.A.; Masugi, Y.; Shi, Y.; Song, M.; da Silva, A.; Gu, M.; et al. Fusobacterium nucleatum in colorectal carcinoma tissue according to tumor location. Clin. Transl. Gastroenterol. 2016, 7, e200. [CrossRef] [PubMed]

109. Sagiv-Barfi, I.; Czerwinski, D.K.; Levy, S.; Alam, I.S.; Mayer, A.T.; Gambhir, S.S.; Levy, R. Eradication of spontaneous malignancy by local immunotherapy. Sci. Transl. Med. 2018, 10, eaan4488. [CrossRef] [PubMed]

110. Kuhn, K.A.; Schulz, H.M.; Regner, E.H.; Severs, E.L.; Hendrickson, J.D.; Mehta, G.; Whitney, A.K.; Ir, D.; Ohri, N.; Robertson, C.E.; et al. Bacteroidales recruit il-6-producing intraepithelial lymphocytes in the colon to promote barrier integrity. Mucosal Immunol. 2017. [CrossRef] [PubMed]

111. Kumari, N.; Dwarakanath, B.S.; Das, A.; Bhatt, A.N. Role of interleukin-6 in cancer progression and therapeutic resistance. Tumour Biol. 2016, 37, 11553-11572. [CrossRef] [PubMed]

112. Moore, P.S.; Chang, Y. Why do viruses cause cancer? Highlights of the first century of human tumour virology. Nat. Rev. Cancer 2010, 10, 878-889. [CrossRef] [PubMed]

113. Falasca, K.; Ucciferri, C.; Dalessandro, M.; Zingariello, P.; Mancino, P.; Petrarca, C.; Pizzigallo, E.; Conti, P.; Vecchiet, J. Cytokine patterns correlate with liver damage in patients with chronic hepatitis $\mathrm{b}$ and $\mathrm{c}$. Ann. Clin. Lab. Sci. 2006, 36, 144-150. [PubMed]

114. Holzerlandt, R.; Orengo, C.; Kellam, P.; Alba, M.M. Identification of new herpesvirus gene homologs in the human genome. Genome Res. 2002, 12, 1739-1748. [CrossRef] [PubMed]

115. Shahanavaj, K.; Gil-Bazo, I.; Castiglia, M.; Bronte, G.; Passiglia, F.; Carreca, A.P.; del Pozo, J.L.; Russo, A.; Peeters, M.; Rolfo, C. Cancer and the microbiome: Potential applications as new tumor biomarker. Expert Rev. Anticancer Ther. 2015, 15, 317-330. [CrossRef] [PubMed]

116. Schwabe, R.F.; Jobin, C. The microbiome and cancer. Nat. Rev. Cancer 2013, 13, 800-812. [CrossRef] [PubMed]

117. Cougnoux, A.; Dalmasso, G.; Martinez, R.; Buc, E.; Delmas, J.; Gibold, L.; Sauvanet, P.; Darcha, C.; Dechelotte, P.; Bonnet, M.; et al. Bacterial genotoxin colibactin promotes colon tumour growth by inducing a senescence-associated secretory phenotype. Gut 2014, 63, 1932-1942. [CrossRef] [PubMed]

118. Arthur, J.C.; Perez-Chanona, E.; Muhlbauer, M.; Tomkovich, S.; Uronis, J.M.; Fan, T.J.; Campbell, B.J.; Abujamel, T.; Dogan, B.; Rogers, A.B.; et al. Intestinal inflammation targets cancer-inducing activity of the microbiota. Science 2012, 338, 120-123. [CrossRef] [PubMed]

119. Dalmasso, G.; Cougnoux, A.; Delmas, J.; Darfeuille-Michaud, A.; Bonnet, R. The bacterial genotoxin colibactin promotes colon tumor growth by modifying the tumor microenvironment. Gut Microbes 2014, 5, 675-680. [CrossRef] [PubMed] 
120. Zhang, Q.; Yu, N.; Lee, C. Mysteries of tgf-beta paradox in benign and malignant cells. Front. Oncol. 2014, 4, 94. [CrossRef] [PubMed]

121. Menzies, B.E. The role of fibronectin binding proteins in the pathogenesis of staphylococcus aureus infections. Curr. Opin. Infect. Dis. 2003, 16, 225-229. [CrossRef] [PubMed]

122. Li, N.; Ren, A.; Wang, X.; Fan, X.; Zhao, Y.; Gao, G.F.; Cleary, P.; Wang, B. Influenza viral neuraminidase primes bacterial coinfection through tgf-beta-mediated expression of host cell receptors. Proc. Natl. Acad. Sci. USA 2015, 112, 238-243. [CrossRef] [PubMed]

123. Xu, P.; Bailey-Bucktrout, S.; Xi, Y.; Xu, D.; Du, D.; Zhang, Q.; Xiang, W.; Liu, J.; Melton, A.; Sheppard, D.; et al. Innate antiviral host defense attenuates tgf-beta function through irf3-mediated suppression of smad signaling. Mol. Cell 2014, 56, 723-737. [CrossRef] [PubMed]

124. Yilmaz, M.; Christofori, G. Emt, the cytoskeleton, and cancer cell invasion. Cancer Metastasis Rev. 2009, 28, 15-33. [CrossRef] [PubMed]

125. Sun, B.O.; Fang, Y.; Li, Z.; Chen, Z.; Xiang, J. Role of cellular cytoskeleton in epithelial-mesenchymal transition process during cancer progression. Biomed. Rep. 2015, 3, 603-610. [CrossRef] [PubMed]

126. Kai, F.; Duncan, R. Prostate cancer cell migration induced by myopodin isoforms is associated with formation of morphologically and biochemically distinct actin networks. FASEB J. 2013, 27, 5046-5058. [CrossRef] [PubMed]

127. Haynes, J.; Srivastava, J.; Madson, N.; Wittmann, T.; Barber, D.L. Dynamic actin remodeling during epithelial-mesenchymal transition depends on increased moesin expression. Mol. Biol. Cell 2011, 22, 4750-4764. [CrossRef] [PubMed]

128. Mouw, J.K.; Ou, G.; Weaver, V.M. Extracellular matrix assembly: A multiscale deconstruction. Nat. Rev. Mol. Cell Biol. 2014, 15, 771-785. [CrossRef] [PubMed]

129. Buret, A.; Gall, D.G.; Olson, M.E.; Hardin, J.A. The role of the epidermal growth factor receptor in microbial infections of the gastrointestinal tract. Microbes Infect. 1999, 1, 1139-1144. [CrossRef]

130. Gunawardhana, N.; Jang, S.; Choi, Y.H.; Hong, Y.A.; Jeon, Y.E.; Kim, A.; Su, H.; Kim, J.H.; Yoo, Y.J.; Merrell, D.S.; et al. Helicobacter pylori-induced hb-egf upregulates gastrin expression via the egf receptor, c-raf, mek1, and erk2 in the mapk pathway. Front. Cell. Infect. Microbiol. 2017, 7, 541. [CrossRef] [PubMed]

131. Higashi, H.; Tsutsumi, R.; Muto, S.; Sugiyama, T.; Azuma, T.; Asaka, M.; Hatakeyama, M. Shp-2 tyrosine phosphatase as an intracellular target of helicobacter pylori caga protein. Science 2002, 295, 683-686. [CrossRef] [PubMed]

132. Kwok, T.; Zabler, D.; Urman, S.; Rohde, M.; Hartig, R.; Wessler, S.; Misselwitz, R.; Berger, J.; Sewald, N.; Konig, W.; et al. Helicobacter exploits integrin for type iv secretion and kinase activation. Nature 2007, 449, 862-866. [CrossRef] [PubMed]

133. Choi, H.J.; Ahn, J.H.; Park, S.H.; Do, K.H.; Kim, J.; Moon, Y. Enhanced wound healing by recombinant escherichia coli nissle 1917 via human epidermal growth factor receptor in human intestinal epithelial cells: Therapeutic implication using recombinant probiotics. Infect. Immun. 2012, 80, 1079-1087. [CrossRef] [PubMed]

134. Dzutsev, A.; Badger, J.H.; Perez-Chanona, E.; Roy, S.; Salcedo, R.; Smith, C.K.; Trinchieri, G. Microbes and cancer. Annu. Rev. Immunol. 2017, 35, 199-228. [CrossRef] [PubMed]

135. Wu, S.; Rhee, K.J.; Albesiano, E.; Rabizadeh, S.; Wu, X.; Yen, H.R.; Huso, D.L.; Brancati, F.L.; Wick, E.; McAllister, F.; et al. A human colonic commensal promotes colon tumorigenesis via activation of $\mathrm{t}$ helper type 17 T cell responses. Nat. Med. 2009, 15, 1016-1022. [CrossRef] [PubMed]

136. Smith, M.I.; Yatsunenko, T.; Manary, M.J.; Trehan, I.; Mkakosya, R.; Cheng, J.; Kau, A.L.; Rich, S.S.; Concannon, P.; Mychaleckyj, J.C.; et al. Gut microbiomes of malawian twin pairs discordant for kwashiorkor. Science 2013, 339, 548-554. [CrossRef] [PubMed]

137. Carbonero, F.; Benefiel, A.C.; Alizadeh-Ghamsari, A.H.; Gaskins, H.R. Microbial pathways in colonic sulfur metabolism and links with health and disease. Front. Physiol. 2012, 3, 448. [CrossRef] [PubMed]

138. Huycke, M.M.; Gaskins, H.R. Commensal bacteria, redox stress, and colorectal cancer: Mechanisms and models. Exp. Biol. Med. 2004, 229, 586-597. [CrossRef]

139. Wang, X.; Huycke, M.M. Extracellular superoxide production by enterococcus faecalis promotes chromosomal instability in mammalian cells. Gastroenterology 2007, 132, 551-561. [CrossRef] [PubMed] 
140. Wang, X.; Yang, Y.; Moore, D.R.; Nimmo, S.L.; Lightfoot, S.A.; Huycke, M.M. 4-hydroxy-2-nonenal mediates genotoxicity and bystander effects caused by enterococcus faecalis-infected macrophages. Gastroenterology 2012, 142, 543-551.e7. [CrossRef] [PubMed]

141. Nesic, D.; Hsu, Y.; Stebbins, C.E. Assembly and function of a bacterial genotoxin. Nature 2004, 429, 429-433. [CrossRef] [PubMed]

142. Simanski, M.; Rademacher, F.; Schroder, L.; Glaser, R.; Harder, J. The inflammasome and the epidermal growth factor receptor (egfr) are involved in the staphylococcus aureus-mediated induction of il-1alpha and il-1beta in human keratinocytes. PLOS ONE 2016, 11, e0147118. [CrossRef] [PubMed]

143. Breshears, L.M.; Schlievert, P.M.; Peterson, M.L. A disintegrin and metalloproteinase 17 (adam17) and epidermal growth factor receptor (egfr) signaling drive the epithelial response to staphylococcus aureus toxic shock syndrome toxin-1 (tsst-1). J. Biol. Chem. 2012, 287, 32578-32587. [CrossRef] [PubMed]

144. Gomez, M.I.; Seaghdha, M.O.; Prince, A.S. Staphylococcus aureus protein a activates tace through egfr-dependent signaling. EMBO J. 2007, 26, 701-709. [CrossRef] [PubMed]

145. Wehkamp, K.; Schwichtenberg, L.; Schroder, J.M.; Harder, J. Pseudomonas aeruginosa- and il-1beta-mediated induction of human beta-defensin-2 in keratinocytes is controlled by nf-kappab and ap-1. J. Investig. Dermatol. 2006, 126, 121-127. [CrossRef] [PubMed]

146. Mariathasan, S.; Weiss, D.S.; Newton, K.; McBride, J.; O’Rourke, K.; Roose-Girma, M.; Lee, W.P.; Weinrauch, Y.; Monack, D.M.; Dixit, V.M. Cryopyrin activates the inflammasome in response to toxins and atp. Nature 2006, 440, 228-232. [CrossRef] [PubMed]

147. Miller, L.S.; Pietras, E.M.; Uricchio, L.H.; Hirano, K.; Rao, S.; Lin, H.; O'Connell, R.M.; Iwakura, Y.; Cheung, A.L.; Cheng, G.; et al. Inflammasome-mediated production of il-1beta is required for neutrophil recruitment against staphylococcus aureus in vivo. J. Immunol. 2007, 179, 6933-6942. [CrossRef] [PubMed]

148. Munoz-Planillo, R.; Franchi, L.; Miller, L.S.; Nunez, G. A critical role for hemolysins and bacterial lipoproteins in staphylococcus aureus-induced activation of the nlrp3 inflammasome. J. Immunol. 2009, 183, 3942-3948. [CrossRef] [PubMed]

149. Shimada, T.; Park, B.G.; Wolf, A.J.; Brikos, C.; Goodridge, H.S.; Becker, C.A.; Reyes, C.N.; Miao, E.A.; Aderem, A.; Gotz, F.; et al. Staphylococcus aureus evades lysozyme-based peptidoglycan digestion that links phagocytosis, inflammasome activation, and il-1beta secretion. Cell Host Microbe 2010, 7, 38-49. [CrossRef] [PubMed]

150. Lichtenberger, B.M.; Gerber, P.A.; Holcmann, M.; Buhren, B.A.; Amberg, N.; Smolle, V.; Schrumpf, H.; Boelke, E.; Ansari, P.; Mackenzie, C.; et al. Epidermal egfr controls cutaneous host defense and prevents inflammation. Sci. Transl. Med. 2013, 5, 199ra111. [CrossRef] [PubMed]

151. Eilers, R.E., Jr.; Gandhi, M.; Patel, J.D.; Mulcahy, M.F.; Agulnik, M.; Hensing, T.; Lacouture, M.E. Dermatologic infections in cancer patients treated with epidermal growth factor receptor inhibitor therapy. J. Natl. Cancer Inst. 2010, 102, 47-53. [CrossRef] [PubMed]

152. Rose-John, S. Adam17, shedding, tace as therapeutic targets. Pharmacol. Res. 2013, 71, 19-22. [CrossRef] [PubMed]

153. Bartok, E.; Bauernfeind, F.; Khaminets, M.G.; Jakobs, C.; Monks, B.; Fitzgerald, K.A.; Latz, E.; Hornung, V. Igluc: A luciferase-based inflammasome and protease activity reporter. Nat. Methods 2013, 10, 147-154. [CrossRef] [PubMed]

154. Johnstone, T.C.; Park, G.Y.; Lippard, S.J. Understanding and improving platinum anticancer drugsPhenanthriplatin. Anticancer Res. 2014, 34, 471-476. [PubMed]

155. Chen, X.; Wu, Y.; Dong, H.; Zhang, C.Y.; Zhang, Y. Platinum-based agents for individualized cancer treatment. Curr. Mol. Med. 2013, 13, 1603-1612. [CrossRef] [PubMed]

156. Bai, L.; Gao, C.; Liu, Q.; Yu, C.; Zhang, Z.; Cai, L.; Yang, B.; Qian, Y.; Yang, J.; Liao, X. Research progress in modern structure of platinum complexes. Eur. J. Med. Chem. 2017, 140, 349-382. [CrossRef] [PubMed]

157. Iida, N.; Dzutsev, A.; Stewart, C.A.; Smith, L.; Bouladoux, N.; Weingarten, R.A.; Molina, D.A.; Salcedo, R.; Back, T.; Cramer, S.; et al. Commensal bacteria control cancer response to therapy by modulating the tumor microenvironment. Science 2013, 342, 967-970. [CrossRef] [PubMed]

158. Galluzzi, L.; Vitale, I.; Michels, J.; Brenner, C.; Szabadkai, G.; Harel-Bellan, A.; Castedo, M.; Kroemer, G. Systems biology of cisplatin resistance: Past, present and future. Cell Death Dis. 2014, 5, e1257. [CrossRef] [PubMed] 
159. Roy, S.; Ryals, M.M.; Van den Bruele, A.B.; Fitzgerald, T.S.; Cunningham, L.L. Sound preconditioning therapy inhibits ototoxic hearing loss in mice. J. Clin. Investig. 2013, 123, 4945-4949. [CrossRef] [PubMed]

160. Zhu, S.; Pabla, N.; Tang, C.; He, L.; Dong, Z. DNA damage response in cisplatin-induced nephrotoxicity. Arch. Toxicol. 2015, 89, 2197-2205. [CrossRef] [PubMed]

161. Park, S.B.; Goldstein, D.; Krishnan, A.V.; Lin, C.S.; Friedlander, M.L.; Cassidy, J.; Koltzenburg, M.; Kiernan, M.C. Chemotherapy-induced peripheral neurotoxicity: A critical analysis. CA Cancer J. Clin. 2013, 63, 419-437. [CrossRef] [PubMed]

162. Gui, Q.F.; Lu, H.F.; Zhang, C.X.; Xu, Z.R.; Yang, Y.H. Well-balanced commensal microbiota contributes to anti-cancer response in a lung cancer mouse model. Genet. Mol. Res. 2015, 14, 5642-5651. [CrossRef] [PubMed]

163. Chitapanarux, I.; Chitapanarux, T.; Traisathit, P.; Kudumpee, S.; Tharavichitkul, E.; Lorvidhaya, V. Randomized controlled trial of live lactobacillus acidophilus plus bifidobacterium bifidum in prophylaxis of diarrhea during radiotherapy in cervical cancer patients. Radiat. Oncol. 2010, 5, 31. [CrossRef] [PubMed]

164. Dhiman, R.K. Gut microbiota and hepatic encephalopathy. Metab. Brain Dis. 2013, 28, 321-326. [CrossRef] [PubMed]

165. Spanogiannopoulos, P.; Bess, E.N.; Carmody, R.N.; Turnbaugh, P.J. The microbial pharmacists within us: A metagenomic view of xenobiotic metabolism. Nat. Rev. Microbiol. 2016, 14, 273-287. [CrossRef] [PubMed]

166. Fujita, K.; Sparreboom, A. Pharmacogenetics of irinotecan disposition and toxicity: A review. Curr. Clin. Pharmacol. 2010, 5, 209-217. [CrossRef] [PubMed]

167. Stringer, A.M.; Gibson, R.J.; Logan, R.M.; Bowen, J.M.; Yeoh, A.S.; Keefe, D.M. Faecal microflora and beta-glucuronidase expression are altered in an irinotecan-induced diarrhea model in rats. Cancer Biol. Ther. 2008, 7, 1919-1925. [CrossRef] [PubMed]

168. McIntosh, F.M.; Maison, N.; Holtrop, G.; Young, P.; Stevens, V.J.; Ince, J.; Johnstone, A.M.; Lobley, G.E.; Flint, H.J.; Louis, P. Phylogenetic distribution of genes encoding beta-glucuronidase activity in human colonic bacteria and the impact of diet on faecal glycosidase activities. Environ. Microbiol. 2012, 14, 1876-1887. [CrossRef] [PubMed]

169. Wallace, B.D.; Wang, H.; Lane, K.T.; Scott, J.E.; Orans, J.; Koo, J.S.; Venkatesh, M.; Jobin, C.; Yeh, L.A.; Mani, S.; et al. Alleviating cancer drug toxicity by inhibiting a bacterial enzyme. Science 2010, 330, 831-835. [CrossRef] [PubMed]

170. Li, H.; Jia, W. Cometabolism of microbes and host: Implications for drug metabolism and drug-induced toxicity. Clin. Pharmacol. Ther. 2013, 94, 574-581. [CrossRef] [PubMed]

171. Maurice, C.F.; Haiser, H.J.; Turnbaugh, P.J. Xenobiotics shape the physiology and gene expression of the active human gut microbiome. Cell 2013, 152, 39-50. [CrossRef] [PubMed]

172. Geller, L.T.; Barzily-Rokni, M.; Danino, T.; Jonas, O.H.; Shental, N.; Nejman, D.; Gavert, N.; Zwang, Y.; Cooper, Z.A.; Shee, K.; et al. Potential role of intratumor bacteria in mediating tumor resistance to the chemotherapeutic drug gemcitabine. Science 2017, 357, 1156-1160. [CrossRef] [PubMed]

173. Oudejans, J.J.; van den Brule, A.J.; Jiwa, N.M.; de Bruin, P.C.; Ossenkoppele, G.J.; van der Valk, P.; Walboomers, J.M.; Meijer, C.J. Bhrf1, the epstein-barr virus (ebv) homologue of the bcl-2 protooncogene, is transcribed in ebv-associated b-cell lymphomas and in reactive lymphocytes. Blood 1995, 86, 1893-1902. [PubMed]

174. Hatton, O.L.; Harris-Arnold, A.; Schaffert, S.; Krams, S.M.; Martinez, O.M. The interplay between epstein-barr virus and b lymphocytes: Implications for infection, immunity, and disease. Immunol. Res. 2014, 58, 268-276. [CrossRef] [PubMed]

175. Kvansakul, M.; Wei, A.H.; Fletcher, J.I.; Willis, S.N.; Chen, L.; Roberts, A.W.; Huang, D.C.; Colman, P.M. Structural basis for apoptosis inhibition by epstein-barr virus bhrf1. PLoS Pathog. 2010, 6, e1001236. [CrossRef] [PubMed]

176. Procko, E.; Berguig, G.Y.; Shen, B.W.; Song, Y.; Frayo, S.; Convertine, A.J.; Margineantu, D.; Booth, G.; Correia, B.E.; Cheng, Y.; et al. A computationally designed inhibitor of an epstein-barr viral bcl-2 protein induces apoptosis in infected cells. Cell 2014, 157, 1644-1656. [CrossRef] [PubMed]

177. Viaud, S.; Saccheri, F.; Mignot, G.; Yamazaki, T.; Daillere, R.; Hannani, D.; Enot, D.P.; Pfirschke, C.; Engblom, C.; Pittet, M.J.; et al. The intestinal microbiota modulates the anticancer immune effects of cyclophosphamide. Science 2013, 342, 971-976. [CrossRef] [PubMed] 
178. Zwielehner, J.; Lassl, C.; Hippe, B.; Pointner, A.; Switzeny, O.J.; Remely, M.; Kitzweger, E.; Ruckser, R.; Haslberger, A.G. Changes in human fecal microbiota due to chemotherapy analyzed by taqman-pcr, 454 sequencing and pcr-dgge fingerprinting. PLoS ONE 2011, 6, e28654. [CrossRef] [PubMed]

179. Daillere, R.; Vetizou, M.; Waldschmitt, N.; Yamazaki, T.; Isnard, C.; Poirier-Colame, V.; Duong, C.P.M.; Flament, C.; Lepage, P.; Roberti, M.P.; et al. Enterococcus hirae and barnesiella intestinihominis facilitate cyclophosphamide-induced therapeutic immunomodulatory effects. Immunity 2016, 45, 931-943. [CrossRef] [PubMed]

180. Couzin-Frankel, J. Breakthrough of the year 2013. Cancer immunotherapy. Science 2013, 342, $1432-1433$. [CrossRef] [PubMed]

181. Sivan, A.; Corrales, L.; Hubert, N.; Williams, J.B.; Aquino-Michaels, K.; Earley, Z.M.; Benyamin, F.W.; Lei, Y.M.; Jabri, B.; Alegre, M.L.; et al. Commensal bifidobacterium promotes antitumor immunity and facilitates anti-pd-11 efficacy. Science 2015, 350, 1084-1089. [CrossRef] [PubMed]

182. Vetizou, M.; Pitt, J.M.; Daillere, R.; Lepage, P.; Waldschmitt, N.; Flament, C.; Rusakiewicz, S.; Routy, B.; Roberti, M.P.; Duong, C.P.; et al. Anticancer immunotherapy by ctla-4 blockade relies on the gut microbiota. Science 2015, 350, 1079-1084. [CrossRef] [PubMed]

183. Routy, B.; Le Chatelier, E.; Derosa, L.; Duong, C.P.M.; Alou, M.T.; Daillere, R.; Fluckiger, A.; Messaoudene, M.; Rauber, C.; Roberti, M.P.; et al. Gut microbiome influences efficacy of pd-1-based immunotherapy against epithelial tumors. Science 2018, 359, 91-97. [CrossRef] [PubMed]

184. Gopalakrishnan, V.; Spencer, C.N.; Nezi, L.; Reuben, A.; Andrews, M.C.; Karpinets, T.V.; Prieto, P.A.; Vicente, D.; Hoffman, K.; Wei, S.C.; et al. Gut microbiome modulates response to anti-pd-1 immunotherapy in melanoma patients. Science 2018, 359, 97-103. [CrossRef] [PubMed]

185. Wei, S.C.; Levine, J.H.; Cogdill, A.P.; Zhao, Y.; Anang, N.A.S.; Andrews, M.C.; Sharma, P.; Wang, J.; Wargo, J.A.; Pe'er, D.; et al. Distinct cellular mechanisms underlie anti-ctla-4 and anti-pd-1 checkpoint blockade. Cell 2017, 170, 1120-1133. [CrossRef] [PubMed]

186. Mazmanian, S.K.; Liu, C.H.; Tzianabos, A.O.; Kasper, D.L. An immunomodulatory molecule of symbiotic bacteria directs maturation of the host immune system. Cell 2005, 122, 107-118. [CrossRef] [PubMed]

187. Mazmanian, S.K.; Round, J.L.; Kasper, D.L. A microbial symbiosis factor prevents intestinal inflammatory disease. Nature 2008, 453, 620-625. [CrossRef] [PubMed]

188. Chung, L.; Thiele Orberg, E.; Geis, A.L.; Chan, J.L.; Fu, K.; Shields, C.E.D.; Dejea, C.M.; Fathi, P.; Chen, J.; Finard, B.B.; et al. Bacteroides fragilis toxin coordinates a pro-carcinogenic inflammatory cascade via targeting of colonic epithelial cells. Cell Host Microbe 2018, 23, 203-214 e205. [CrossRef] [PubMed]

189. Vieira, A.R.; Abar, L.; Vingeliene, S.; Chan, D.S.; Aune, D.; Navarro-Rosenblatt, D.; Stevens, C.; Greenwood, D.; Norat, T. Fruits, vegetables and lung cancer risk: A systematic review and meta-analysis. Ann. Oncol. 2016, 27, 81-96. [CrossRef] [PubMed]

190. Wang, M.; Qin, S.; Zhang, T.; Song, X.; Zhang, S. The effect of fruit and vegetable intake on the development of lung cancer: A meta-analysis of 32 publications and 20,414 cases. Eur. J. Clin. Nutr. 2015, 69, 1184-1192. [CrossRef] [PubMed]

191. Liu, J.; Wang, J.; Leng, Y.; Lv, C. Intake of fruit and vegetables and risk of esophageal squamous cell carcinoma: A meta-analysis of observational studies. Int. J. Cancer 2013, 133, 473-485. [CrossRef] [PubMed]

192. Maasland, D.H.; van den Brandt, P.A.; Kremer, B.; Goldbohm, R.A.; Schouten, L.J. Consumption of vegetables and fruits and risk of subtypes of head-neck cancer in the netherlands cohort study. Int. J. Cancer 2015, 136, E396-E409. [CrossRef] [PubMed]

193. Larsson, S.C.; Bergkvist, L.; Wolk, A. Fruit and vegetable consumption and incidence of gastric cancer: A prospective study. Cancer Epidemiol. Biomark. Prev. 2006, 15, 1998-2001. [CrossRef] [PubMed]

194. Lunet, N.; Valbuena, C.; Vieira, A.L.; Lopes, C.; Lopes, C.; David, L.; Carneiro, F.; Barros, H. Fruit and vegetable consumption and gastric cancer by location and histological type: Case-control and meta-analysis. Eur. J. Cancer Prev. 2007, 16, 312-327. [CrossRef] [PubMed]

195. Slavin, J.L.; Lloyd, B. Health benefits of fruits and vegetables. Adv. Nutr. 2012, 3, 506-516. [CrossRef] [PubMed]

196. Martinez, M.E.; Jacobs, E.T.; Baron, J.A.; Marshall, J.R.; Byers, T. Dietary supplements and cancer prevention: Balancing potential benefits against proven harms. J. Natl. Cancer Inst. 2012, 104, 732-739. [CrossRef] [PubMed] 
197. Bjelakovic, G.; Nikolova, D.; Gluud, L.L.; Simonetti, R.G.; Gluud, C. Antioxidant supplements for prevention of mortality in healthy participants and patients with various diseases. Cochrane Database Syst. Rev. 2012, CD007176. [CrossRef] [PubMed]

198. Hehemann, J.H.; Correc, G.; Barbeyron, T.; Helbert, W.; Czjzek, M.; Michel, G. Transfer of carbohydrate-active enzymes from marine bacteria to japanese gut microbiota. Nature 2010, 464, 908-912. [CrossRef] [PubMed]

199. Vaikundamoorthy, R.; Krishnamoorthy, V.; Vilwanathan, R.; Rajendran, R. Structural characterization and anticancer activity (mcf7 and mda-mb-231) of polysaccharides fractionated from brown seaweed sargassum wightii. Int. J. Biol. Macromol. 2018, 111, 1229-1237. [CrossRef] [PubMed]

200. Abedin-Do, A.; Taherian-Esfahani, Z.; Ghafouri-Fard, S.; Ghafouri-Fard, S.; Motevaseli, E. Immunomodulatory effects of lactobacillus strains: Emphasis on their effects on cancer cells. Immunotherapy 2015, 7, 1307-1329. [CrossRef] [PubMed]

201. Chen, C.; Chan, H.M.; Kubow, S. Kefir extracts suppress in vitro proliferation of estrogen-dependent human breast cancer cells but not normal mammary epithelial cells. J. Med. Food 2007, 10, 416-422. [CrossRef] [PubMed]

202. Konishi, H.; Fujiya, M.; Tanaka, H.; Ueno, N.; Moriichi, K.; Sasajima, J.; Ikuta, K.; Akutsu, H.; Tanabe, H.; Kohgo, Y. Probiotic-derived ferrichrome inhibits colon cancer progression via jnk-mediated apoptosis. Nat. Commun. 2016, 7, 12365. [CrossRef] [PubMed]

203. Wilkins, T.; Sequoia, J. Probiotics for gastrointestinal conditions: A summary of the evidence. Am. Fam. Phys. 2017, 96, 170-178.

204. Chan, D.S.; Lau, R.; Aune, D.; Vieira, R.; Greenwood, D.C.; Kampman, E.; Norat, T. Red and processed meat and colorectal cancer incidence: Meta-analysis of prospective studies. PLoS ONE 2011, 6, e20456. [CrossRef] [PubMed]

205. Larsson, S.C.; Wolk, A. Meat consumption and risk of colorectal cancer: A meta-analysis of prospective studies. Int. J. Cancer 2006, 119, 2657-2664. [CrossRef] [PubMed]

206. Norat, T.; Bingham, S.; Ferrari, P.; Slimani, N.; Jenab, M.; Mazuir, M.; Overvad, K.; Olsen, A.; Tjonneland, A.; Clavel, F.; et al. Meat, fish, and colorectal cancer risk: The european prospective investigation into cancer and nutrition. J. Natl. Cancer Inst. 2005, 97, 906-916. [CrossRef] [PubMed]

207. Bouvard, V.; Loomis, D.; Guyton, K.Z.; Grosse, Y.; Ghissassi, F.E.; Benbrahim-Tallaa, L.; Guha, N.; Mattock, H.; Straif, K.; International Agency for Research on Cancer Monograph Working Group. Carcinogenicity of consumption of red and processed meat. Lancet Oncol. 2015, 16, 1599-1600. [CrossRef]

208. Larsson, S.C.; Wolk, A. Red and processed meat consumption and risk of pancreatic cancer: Meta-analysis of prospective studies. Br. J. Cancer 2012, 106, 603-607. [CrossRef] [PubMed]

209. Zhu, H.; Yang, X.; Zhang, C.; Zhu, C.; Tao, G.; Zhao, L.; Tang, S.; Shu, Z.; Cai, J.; Dai, S.; et al. Red and processed meat intake is associated with higher gastric cancer risk: A meta-analysis of epidemiological observational studies. PLoS ONE 2013, 8, e70955. [CrossRef] [PubMed]

210. Bylsma, L.C.; Alexander, D.D. A review and meta-analysis of prospective studies of red and processed meat, meat cooking methods, heme iron, heterocyclic amines and prostate cancer. Nutr. J. 2015, 14, 125. [CrossRef] [PubMed]

211. Cross, A.J.; Pollock, J.R.; Bingham, S.A. Haem, not protein or inorganic iron, is responsible for endogenous intestinal n-nitrosation arising from red meat. Cancer Res. 2003, 63, 2358-2360. [PubMed]

212. Sinha, R.; Peters, U.; Cross, A.J.; Kulldorff, M.; Weissfeld, J.L.; Pinsky, P.F.; Rothman, N.; Hayes, R.B. Meat, meat cooking methods and preservation, and risk for colorectal adenoma. Cancer Res. 2005, 65, 8034-8041. [CrossRef] [PubMed]

213. Cummings, J.H.; Bingham, S.A. Dietary fibre, fermentation and large bowel cancer. Cancer Surv. 1987, 6, 601-621. [PubMed]

214. van der Beek, C.M.; Dejong, C.H.C.; Troost, F.J.; Masclee, A.A.M.; Lenaerts, K. Role of short-chain fatty acids in colonic inflammation, carcinogenesis, and mucosal protection and healing. Nutr. Rev. 2017, 75, 286-305. [CrossRef] [PubMed]

215. Sivaprakasam, S.; Bhutia, Y.D.; Yang, S.; Ganapathy, V. Short-chain fatty acid transporters: Role in colonic homeostasis. Compr. Physiol. 2017, 8, 299-314. [PubMed]

216. Maslowski, K.M.; Vieira, A.T.; Ng, A.; Kranich, J.; Sierro, F.; Yu, D.; Schilter, H.C.; Rolph, M.S.; Mackay, F.; Artis, D.; et al. Regulation of inflammatory responses by gut microbiota and chemoattractant receptor gpr43. Nature 2009, 461, 1282-1286. [CrossRef] [PubMed] 
217. Weitkunat, K.; Schumann, S.; Petzke, K.J.; Blaut, M.; Loh, G.; Klaus, S. Effects of dietary inulin on bacterial growth, short-chain fatty acid production and hepatic lipid metabolism in gnotobiotic mice. J. Nutr. Biochem. 2015, 26, 929-937. [CrossRef] [PubMed]

218. Bindels, L.B.; Porporato, P.; Dewulf, E.M.; Verrax, J.; Neyrinck, A.M.; Martin, J.C.; Scott, K.P.; Buc Calderon, P.; Feron, O.; Muccioli, G.G.; et al. Gut microbiota-derived propionate reduces cancer cell proliferation in the liver. Br. J. Cancer 2012, 107, 1337-1344. [CrossRef] [PubMed]

219. Hu, S.; Dong, T.S.; Dalal, S.R.; Wu, F.; Bissonnette, M.; Kwon, J.H.; Chang, E.B. The microbe-derived short chain fatty acid butyrate targets mirna-dependent $\mathrm{p} 21$ gene expression in human colon cancer. PLoS ONE 2011, 6, e16221. [CrossRef] [PubMed]

220. Ogino, S.; Nosho, K.; Shima, K.; Baba, Y.; Irahara, N.; Kirkner, G.J.; Hazra, A.; De Vivo, I.; Giovannucci, E.L.; Meyerhardt, J.A.; et al. P21 expression in colon cancer and modifying effects of patient age and body mass index on prognosis. Cancer Epidemiol. Biomark. Prev. 2009, 18, 2513-2521. [CrossRef] [PubMed]

221. Aune, D.; Chan, D.S.; Lau, R.; Vieira, R.; Greenwood, D.C.; Kampman, E.; Norat, T. Dietary fibre, whole grains, and risk of colorectal cancer: Systematic review and dose-response meta-analysis of prospective studies. BMJ 2011, 343, d6617. [CrossRef] [PubMed]

222. Fahey, J.W.; Holtzclaw, W.D.; Wehage, S.L.; Wade, K.L.; Stephenson, K.K.; Talalay, P. Sulforaphane bioavailability from glucoraphanin-rich broccoli: Control by active endogenous myrosinase. PLOS ONE 2015, 10, e0140963. [CrossRef] [PubMed]

223. Fahey, J.W.; Wehage, S.L.; Holtzclaw, W.D.; Kensler, T.W.; Egner, P.A.; Shapiro, T.A.; Talalay, P. Protection of humans by plant glucosinolates: Efficiency of conversion of glucosinolates to isothiocyanates by the gastrointestinal microflora. Cancer Prev. Res. 2012, 5, 603-611. [CrossRef] [PubMed]

224. Wang, F.; Wang, W.; Li, J.; Zhang, J.; Wang, X.; Wang, M. Sulforaphane reverses gefitinib tolerance in human lung cancer cells via modulation of sonic hedgehog signaling. Oncol. Lett. 2018, 15, 109-114. [CrossRef] [PubMed]

225. Egner, P.A.; Chen, J.G.; Wang, J.B.; Wu, Y.; Sun, Y.; Lu, J.H.; Zhu, J.; Zhang, Y.H.; Chen, Y.S.; Friesen, M.D.; et al. Bioavailability of sulforaphane from two broccoli sprout beverages: Results of a short-term, cross-over clinical trial in qidong, china. Cancer Prev. Res. 2011, 4, 384-395. [CrossRef] [PubMed]

226. Huang, L.L.B.L.; He, C.X.; Zhao, Y.J.; Yang, X.L.; Pang, B.; Zhang, X.H.; Shan, Y.J. Sulforaphane inhibits human bladder cancer cell invasion by reversing epithelial-to-mesenchymal transition via directly targeting microrna-200c/zeb1 axis. J. Funct. Foods 2018, 41, 118-126. [CrossRef]

227. Hullar, M.A.; Lancaster, S.M.; Li, F.; Tseng, E.; Beer, K.; Atkinson, C.; Wahala, K.; Copeland, W.K.; Randolph, T.W.; Newton, K.M.; et al. Enterolignan-producing phenotypes are associated with increased gut microbial diversity and altered composition in premenopausal women in the united states. Cancer Epidemiol. Biomark. Prev. 2015, 24, 546-554. [CrossRef] [PubMed]

228. Ward, H.A.; Kuhnle, G.G.; Mulligan, A.A.; Lentjes, M.A.; Luben, R.N.; Khaw, K.T. Breast, colorectal, and prostate cancer risk in the european prospective investigation into cancer and nutrition-norfolk in relation to phytoestrogen intake derived from an improved database. Am. J. Clin. Nutr. 2010, 91, 440-448. [CrossRef] [PubMed]

229. Praengam, K.; Sahasakul, Y.; Kupradinun, P.; Sakarin, S.; Sanitchua, W.; Rungsipipat, A.; Rattanapinyopituk, K.; Angkasekwinai, P.; Changsri, K.; Mhuantong, W.; et al. Brown rice and retrograded brown rice alleviate inflammatory response in dextran sulfate sodium (dss)-induced colitis mice. Food Funct. 2017, 8, 4630-4643. [CrossRef] [PubMed]

230. Shivappa, N.; Godos, J.; Hebert, J.R.; Wirth, M.D.; Piuri, G.; Speciani, A.F.; Grosso, G. Dietary inflammatory index and colorectal cancer risk-a meta-analysis. Nutrients 2017, 9, 1043. [CrossRef] [PubMed]

231. Shivappa, N.; Steck, S.E.; Hurley, T.G.; Hussey, J.R.; Hebert, J.R. Designing and developing a literature-derived, population-based dietary inflammatory index. Public Health Nutr. 2014, 17, 1689-1696. [CrossRef] [PubMed]

232. Kim, K.; Vance, T.M.; Chun, O.K. Estimated intake and major food sources of flavonoids among us adults: Changes between 1999-2002 and 2007-2010 in nhanes. Eur. J. Nutr. 2016, 55, 833-843. [CrossRef] [PubMed]

233. Etxeberria, U.; Arias, N.; Boque, N.; Macarulla, M.T.; Portillo, M.P.; Martinez, J.A.; Milagro, F.I. Reshaping faecal gut microbiota composition by the intake of trans-resveratrol and quercetin in high-fat sucrose diet-fed rats. J. Nutr. Biochem. 2015, 26, 651-660. [CrossRef] [PubMed] 
234. Shen, L.; Liu, L.; Ji, H.F. Regulative effects of curcumin spice administration on gut microbiota and its pharmacological implications. Food Nutr. Res. 2017, 61, 1361780. [CrossRef] [PubMed]

235. McFadden, R.M.; Larmonier, C.B.; Shehab, K.W.; Midura-Kiela, M.; Ramalingam, R.; Harrison, C.A.; Besselsen, D.G.; Chase, J.H.; Caporaso, J.G.; Jobin, C.; et al. The role of curcumin in modulating colonic microbiota during colitis and colon cancer prevention. Inflamm. Bowel Dis. 2015, 21, 2483-2494. [CrossRef] [PubMed]

236. Chang, J.H.; Shim, Y.Y.; Cha, S.K.; Reaney, M.J.; Chee, K.M. Effect of lactobacillus acidophilus kfri342 on the development of chemically induced precancerous growths in the rat colon. J. Med. Microbiol. 2012, 61, 361-368. [CrossRef] [PubMed]

237. Guallar, E.; Stranges, S.; Mulrow, C.; Appel, L.J.; Miller, E.R., 3rd. Enough is enough: Stop wasting money on vitamin and mineral supplements. Ann. Intern. Med. 2013, 159, 850-851. [CrossRef] [PubMed]

238. Bjelakovic, G.; Gluud, L.L.; Nikolova, D.; Whitfield, K.; Krstic, G.; Wetterslev, J.; Gluud, C. Vitamin d supplementation for prevention of cancer in adults. Cochrane Database Syst. Rev. 2014, CD007469. [CrossRef] [PubMed]

239. Vinceti, M.; Filippini, T.; Del Giovane, C.; Dennert, G.; Zwahlen, M.; Brinkman, M.; Zeegers, M.P.; Horneber, M.; D'Amico, R.; Crespi, C.M. Selenium for preventing cancer. Cochrane Database Syst. Rev. 2018, 1, CD005195. [CrossRef] [PubMed]

240. Cortés-Jofré, M.; Rueda, J.R.; Corsini-Muñoz, G.; Fonseca-Cortés, C.; Caraballoso, M.; Bonfill Cosp, X. Antioxidant drugs for preventing lung cancer in healthy people. Cochrane Database Syst. Rev. 2012. [CrossRef]

241. Bjelakovic, G.; Nikolova, D.; Simonetti, R.G.; Gluud, C. Antioxidant supplements for preventing gastrointestinal cancers. Cochrane Database Syst. Rev. 2008, CD004183. [CrossRef] [PubMed]

242. Fang, H.; Kang, J.; Zhang, D. Microbial production of vitamin b12: A review and future perspectives. Microb. Cell Fact. 2017, 16, 15. [CrossRef] [PubMed]

243. Reid, I.R.; Ibbertson, H.K. Calcium supplements in the prevention of steroid-induced osteoporosis. Am. J. Clin. Nutr. 1986, 44, 287-290. [CrossRef] [PubMed]

244. Valentin, M.; Coste Mazeau, P.; Zerah, M.; Ceccaldi, P.F.; Benachi, A.; Luton, D. Acid folic and pregnancy: A mandatory supplementation. Ann. D'endocrinol. 2018. [CrossRef] [PubMed]

245. Forrest, K.Y.; Stuhldreher, W.L. Prevalence and correlates of vitamin d deficiency in us adults. Nutr. Res. 2011, 31, 48-54. [CrossRef] [PubMed]

246. Klaunig, J.E. Acrylamide carcinogenicity. J. Agric. Food Chem. 2008, 56, 5984-5988. [CrossRef] [PubMed]

247. Dearfield, K.L.; Abernathy, C.O.; Ottley, M.S.; Brantner, J.H.; Hayes, P.F. Acrylamide: Its metabolism, developmental and reproductive effects, genotoxicity, and carcinogenicity. Mutat. Res. 1988, 195, 45-77. [CrossRef]

248. Bian, X.; Tu, P.; Chi, L.; Gao, B.; Ru, H.; Lu, K. Saccharin induced liver inflammation in mice by altering the gut microbiota and its metabolic functions. Food Chem. Toxicol. 2017, 107, 530-539. [CrossRef] [PubMed]

249. Soffritti, M.; Padovani, M.; Tibaldi, E.; Falcioni, L.; Manservisi, F.; Lauriola, M.; Belpoggi, F. Sucralose administered in feed, beginning prenatally through lifespan, induces hematopoietic neoplasias in male swiss mice. Int. J. Occup. Environ. Health 2016, 22, 7-17.

250. Wang, J.L.; Lin, Y.W.; Chen, H.M.; Kong, X.; Xiong, H.; Shen, N.; Hong, J.; Fang, J.Y. Calcium prevents tumorigenesis in a mouse model of colorectal cancer. PLoS ONE 2011, 6, e22566. [CrossRef] [PubMed]

251. Virk-Baker, M.K.; Nagy, T.R.; Barnes, S.; Groopman, J. Dietary acrylamide and human cancer: A systematic review of literature. Nutr. Cancer 2014, 66, 774-790. [CrossRef] [PubMed]

252. Lipworth, L.; Sonderman, J.S.; Tarone, R.E.; McLaughlin, J.K. Review of epidemiologic studies of dietary acrylamide intake and the risk of cancer. Eur. J. Cancer Prev. 2012, 21, 375-386. [CrossRef] [PubMed]

253. Lohner, S.; Toews, I.; Meerpohl, J.J. Health outcomes of non-nutritive sweeteners: Analysis of the Research landscape. Nutr. J. 2017, 16, 55. [CrossRef] [PubMed]

254. Bristow, S.M.; Bolland, M.J.; MacLennan, G.S.; Avenell, A.; Grey, A.; Gamble, G.D.; Reid, I.R. Calcium supplements and cancer risk: A meta-analysis of randomised controlled trials. Br. J. Nutr. 2013, 110, 1384-1393. [CrossRef] [PubMed]

255. Duda-Chodak, A.; Wajda, L.; Tarko, T.; Sroka, P.; Satora, P. A review of the interactions between acrylamide, microorganisms and food components. Food Funct. 2016, 7, 1282-1295. [CrossRef] [PubMed]

256. Joshi, S.J.; Abed, R.M.M. Biodegradation of polyacrylamide and its derivatives. Environ. Process. 2017, 4, 463-476. 
257. Suez, J.; Korem, T.; Zeevi, D.; Zilberman-Schapira, G.; Thaiss, C.A.; Maza, O.; Israeli, D.; Zmora, N.; Gilad, S.; Weinberger, A.; et al. Artificial sweeteners induce glucose intolerance by altering the gut microbiota. Nature 2014, 514, 181-186. [CrossRef] [PubMed]

258. Uebanso, T.; Ohnishi, A.; Kitayama, R.; Yoshimoto, A.; Nakahashi, M.; Shimohata, T.; Mawatari, K.; Takahashi, A. Effects of low-dose non-caloric sweetener consumption on gut microbiota in mice. Nutrients 2017, 9, 560. [CrossRef] [PubMed]

259. Palmnas, M.S.; Cowan, T.E.; Bomhof, M.R.; Su, J.; Reimer, R.A.; Vogel, H.J.; Hittel, D.S.; Shearer, J. Low-dose aspartame consumption differentially affects gut microbiota-host metabolic interactions in the diet-induced obese rat. PLoS ONE 2014, 9, e109841. [CrossRef] [PubMed]

260. Bian, X.; Chi, L.; Gao, B.; Tu, P.; Ru, H.; Lu, K. The artificial sweetener acesulfame potassium affects the gut microbiome and body weight gain in cd-1 mice. PLoS ONE 2017, 12, e0178426. [CrossRef] [PubMed]

261. Dominguez, D.C. Calcium signalling in bacteria. Mol. Microbiol. 2004, 54, 291-297. [CrossRef] [PubMed]

262. Yi, W.; Fischer, J.; Krewer, G.; Akoh, C.C. Phenolic compounds from blueberries can inhibit colon cancer cell proliferation and induce apoptosis. J. Agric. Food Chem. 2005, 53, 7320-7329. [CrossRef] [PubMed]

263. Hassimotto, N.M.; Genovese, M.I.; Lajolo, F.M. Antioxidant activity of dietary fruits, vegetables, and commercial frozen fruit pulps. J. Agric. Food Chem. 2005, 53, 2928-2935. [CrossRef] [PubMed]

264. Henning, S.M.; Niu, Y.; Lee, N.H.; Thames, G.D.; Minutti, R.R.; Wang, H.; Go, V.L.; Heber, D. Bioavailability and antioxidant activity of tea flavanols after consumption of green tea, black tea, or a green tea extract supplement. Am. J. Clin. Nutr. 2004, 80, 1558-1564. [CrossRef] [PubMed]

265. Khan, N.; Mukhtar, H. Cancer and metastasis: Prevention and treatment by green tea. Cancer Metastasis Rev. 2010, 29, 435-445. [CrossRef] [PubMed]

266. Sartippour, M.R.; Heber, D.; Ma, J.; Lu, Q.; Go, V.L.; Nguyen, M. Green tea and its catechins inhibit breast cancer xenografts. Nutr. Cancer 2001, 40, 149-156. [CrossRef] [PubMed]

267. Ankolekar, C.; Johnson, D.; Pinto Mda, S.; Johnson, K.; Labbe, R.; Shetty, K. Inhibitory potential of tea polyphenolics and influence of extraction time against helicobacter pylori and lack of inhibition of beneficial lactic acid bacteria. J. Med. Food 2011, 14, 1321-1329. [CrossRef] [PubMed]

268. Boehm, K.; Borrelli, F.; Ernst, E.; Habacher, G.; Hung, S.K.; Milazzo, S.; Horneber, M. Green tea (camellia sinensis) for the prevention of cancer. Cochrane Database Syst. Rev. 2009, CD005004. [CrossRef] [PubMed]

269. Zhang, Y.F.; Xu, Q.; Lu, J.; Wang, P.; Zhang, H.W.; Zhou, L.; Ma, X.Q.; Zhou, Y.H. Tea consumption and the incidence of cancer: A systematic review and meta-analysis of prospective observational studies. Eur. J. Cancer Prev. 2015, 24, 353-362. [CrossRef] [PubMed]

270. Rady, I.M.H.; Rady, M.; Siddiqui, I.A.; Mukhtar, H. Cancer preventive and therapeutic effects of egcg, the major polyphenol in green tea. Egypt. J. Basic Appl. Sci. 2017, 5, 1-23. [CrossRef]

271. Cardona, F.; Andres-Lacueva, C.; Tulipani, S.; Tinahones, F.J.; Queipo-Ortuno, M.I. Benefits of polyphenols on gut microbiota and implications in human health. J. Nutr. Biochem. 2013, 24, 1415-1422. [CrossRef] [PubMed]

272. Wang, C.M.; Li, T.C.; Jhan, Y.L.; Weng, J.H.; Chou, C.H. The impact of microbial biotransformation of catechin in enhancing the allelopathic effects of rhododendron formosanum. PLoS ONE 2013, 8, e85162. [CrossRef] [PubMed]

273. Lin, H.H.; Chen, J.H.; Chou, F.P.; Wang, C.J. Protocatechuic acid inhibits cancer cell metastasis involving the down-regulation of ras/akt/nf-kappab pathway and mmp-2 production by targeting rhob activation. Br. J. Pharmacol. 2011, 162, 237-254. [CrossRef] [PubMed]

274. Batra, P.; Sharma, A.K. Anti-cancer potential of flavonoids: Recent trends and future perspectives. 3 Biotech 2013, 3, 439-459. [CrossRef] [PubMed]

275. Cao, H.; Chen, X.; Jassbi, A.R.; Xiao, J. Microbial biotransformation of bioactive flavonoids. Biotechnol. Adv. 2015, 33, 214-223. [CrossRef] [PubMed]

276. Anthony, M.S.; Clarkson, T.B.; Hughes, C.L., Jr.; Morgan, T.M.; Burke, G.L. Soybean isoflavones improve cardiovascular risk factors without affecting the reproductive system of peripubertal rhesus monkeys. J. Nutr. 1996, 126, 43-50. [CrossRef] [PubMed]

277. Whitten, P.L.; Patisaul, H.B. Cross-species and interassay comparisons of phytoestrogen action. Environ. Health Perspect. 2001, 109 (Suppl. 1), 5-20. [CrossRef] [PubMed] 
278. Lephart, E.D.; Setchell, K.D.; Handa, R.J.; Lund, T.D. Behavioral effects of endocrine-disrupting substances: Phytoestrogens. ILAR J. 2004, 45, 443-454. [CrossRef] [PubMed]

279. Xiao, C.W. Health effects of soy protein and isoflavones in humans. J. Nutr. 2008, 138, 1244S-1249S. [CrossRef] [PubMed]

280. Tsuchihashi, R.; Sakamoto, S.; Kodera, M.; Nohara, T.; Kinjo, J. Microbial metabolism of soy isoflavones by human intestinal bacterial strains. J. Nat. Med. 2008, 62, 456-460. [CrossRef] [PubMed]

(c)

(C) 2018 by the authors. Licensee MDPI, Basel, Switzerland. This article is an open access article distributed under the terms and conditions of the Creative Commons Attribution (CC BY) license (http://creativecommons.org/licenses/by/4.0/). 